This article should be cited as: Sharifzadeh $\mathrm{M}^{\star}$, Richard CJ, Liu K, Hellgardt K, Chadwick D, Shah N. (2015). An integrated process for biomass pyrolysis oil upgrading: the synergistic approach. Biomass \& Bioenergy. 76, 108-117, (Link).

\title{
1 An Integrated Process for Biomass Pyrolysis Oil Upgrading: A Synergistic
}

\section{Approach}

M. Sharifzadeh ${ }^{a 1}$, C. Richard ${ }^{b}$, K. Liu ${ }^{b}$, K. Hellgardt ${ }^{b}$, D. Chadwick ${ }^{b}$ and N. Shah ${ }^{a}$

4

5 Abstract- Biomass pyrolysis is a promising path toward renewable liquid fuels. However, the calorific value of the pyrolysis oil (PO), also known as bio-oil, is low due to the high content of organic oxygenates and water. The oxygen content of PO can be reduced by hydrodeoxygenation, in which hydrogen is used to remove oxygen. An economic disadvantage of hydrodeoxygenation pathway is its dependence on hydrogen as an expensive feedstock. An alternative technology is to upgrade PO in hot, high pressure water, known as hydrothermal processing. The present paper studies upgrading pyrolysis oil derived from Norwegian spruce by (1) hydrodeoxygenation in a liquid hydrocarbon solvent using nanodispersed sulphide catalysts and (2) hydrothermal treatment in near-supercritical water. Experimental results and simulation studies suggested that if water soluble products are reformed for hydrogen production, the hydrodeoxygenation pathway would be a net consumer of hydrogen, whilst the hydrothermal pathway could produce a significant hydrogen excess. By comparison, the fuel yield from hydrodeoxygenation was significantly higher than hydrothermally treated fuel. Therefore, in the present study, an integrated model was proposed which demonstrates that the synergistic integration of hydrothermal and hydrodeoxygenation upgrading technologies can yield an optimal configuration which maximises fuel production, whilst obviating the need to purchase hydrogen. In this optimal configuration, $32 \%$ of raw pyrolysis-oil is hydrothermally treated and the rest is sent for hydrodeoxygenation. The results of a techno-economic analysis suggests that if the proposed integrated approach is used, it is possible to produce biofuel (43\% gasoline, and $57 \%$ diesel) at a very competitive minimum selling price of $428 \$ \mathrm{~m}^{-3}$ (1.62 $\$$ /gallon).

Key words: Biomass fast pyrolysis, Pyrolysis oil upgrading, hydrodeoxygenation, hydrothermal treatment,

\footnotetext{
${ }^{1}$ Corresponding Author: Dr Mahdi Sharifzadeh; Room C603, Roderic Hill Building, South Kensington Campus, Imperial College London, UK. SW7 2AZ. E-mail: mahdi@imperial.ac.uk; Tel: +44(0)7517853422
} 
This article should be cited as: Sharifzadeh $\mathrm{M}^{\star}$, Richard CJ, Liu K, Hellgardt K, Chadwick D, Shah N. (2015). An integrated process for biomass pyrolysis oil upgrading: the synergistic approach. Biomass \& Bioenergy. 76, 108-117, (Link).

\section{Introduction}

The production of liquid fuels from biomass has the potential to diversify energy resources and mitigate the environmental impacts associated with consumption of fossil-based energy resources. Amongst various conversion pathways such as fermentation, hydrothermal liquefaction, pyrolysis, and gasification [1], pyrolysis offers the cheapest route to renewable liquid fuels. Nonetheless, many aspects of the pyrolysis pathway are still under investigation. The diverse array of research into biomass pyrolysis is multi-disciplinary and multi-dimensional and includes Pyrolysis Oil (PO) characterization [2-4], kinetic studies [5,6], computational fluid dynamics [7], design of new reactors [8], microwave assisted pyrolysis [9-10], optimizing the PO yield [11], process intensification [12], techno-economic analysis $[13,14]$ environmental assessment [15], in addition to enterprise-wide and supply chain optimization [16-18].

Despite various economic incentives, commercialization of biomass pyrolysis poses an important challenge; the product of the pyrolysis reactions, called Pyrolysis Oil (PO), suffers from undesirable properties. It has a high level of organic oxygenates which results in a low calorific value. PO is highly acidic, and chemically unstable, which leads to polymerization and gradual increases in its viscosity. In addition, due to the high water content (ca. 0.35 mass fraction) it is immiscible with conventional fossil fuels. The technologies for the removal of oxygen and other heteroatoms in PO are referred to as "upgrading". Hydrodeoxygenation is the most common upgrading technology and was originally inspired by hydrodesulfurization (HDS) and hydrodenitrogenation (HDN) from the petroleum refining industry and coal liquefaction [19-23]. However, the amount of heteroatoms (i.e., oxygen) is an order of magnitude larger in the case of PO. The high oxygen content can lead to excess coke formation [24]. As a resolution multistage hydrodeoxygenation has been proposed in which first the PO is stabilized in a low temperature reactor and then a deeper hydrodeoxygenation (HDO) is accomplished in the second-stage reactor at a higher temperature [25-27]. While hydrodeoxygenation does not alter the boiling range of hydrocarbons significantly, cracking and 
This article should be cited as: Sharifzadeh $\mathrm{M}^{\star}$, Richard CJ, Liu K, Hellgardt K, Chadwick D, Shah N. (2015). An integrated process for biomass pyrolysis oil upgrading: the synergistic approach. Biomass \& Bioenergy. 76, 108-117, (Link).

hydrocracking using zeolites are efficient methods to reduce the size of product molecules by depolymerisation of heavy oligomers [28]. However, coking can be so severe that a fixed bed reactor may become plugged quickly. Pretreatment using multistage HDO can mitigate the problem [29].

Recent research concerning catalysts for a low temperature first stage PO upgrading has tended towards supported precious metals especially Ru or Pd with carbon as a support (e.g. [26], [30]). In contrast, conventional refinery hydrotreating catalysts are based on Co-Mo or Ni-Mo sulphides supported on alumina. These catalysts have found wide application in PO upgrading research [2023]. The use of a slurry reactor for a first stage catalytic hydrodeoxygenation has several attractions [31]. It offers better temperature control which assists with control of coke formation, facilitates catalyst withdrawal and replacement, and permits the use of microcatalysts. The present study of pyrolysis oil upgrading is concerned with the use of unsupported mixed sulphide nanoparticle catalysts. These are dispersed throughout the bulk of the pyrolysis oil/solvent liquid aiding the rapid hydrogenation of free radicals, coke precursors, suppression of polymerisation etc. leading to stabilisation of the oil. Nanoparticle catalysts also eliminate limitations which might arise from internal mass transfer associated with the support pore structure. Unsupported nanosulphide catalysts have been used in the hydrotreatment of heavy and residual oils [31], [32-34] and in coal liquefaction [35]. Typically, the mass fractions of the catalysts were between $5 \times 10^{-4}-10^{-2}(500$ $10,000 \mathrm{ppm}$ of metal) [32-33]. In the present work, Mo and Ni nanosulphides have been used in combination as catalysts in the slurry phase for the first stage hydrodeoxygenation of the pyrolysis oil. Mo and Ni nanosulphides were preferred due to the performance of Ni-Mo supported catalysts for HDO (e.g. [36]). To our knowledge, this is the first time unsupported nanosulphide catalysts have been used in the upgrading of pyrolysis oil (a recent patent application did not include any experimental examples [37]).

An alternative process for the conversion of biomass to liquid fuels uses hot compressed water (HCW) as a reaction medium. This "hydrothermal upgrading" technology dates back to pioneering research in the 1970s to 1990s by Shell [38]. In hydrothermal upgrading (also known as aqueous- 
This article should be cited as: Sharifzadeh $\mathrm{M}^{\star}$, Richard CJ, Liu K, Hellgardt K, Chadwick D, Shah N. (2015). An integrated process for biomass pyrolysis oil upgrading: the synergistic approach.

Biomass \& Bioenergy. 76, 108-117, (Link).

phase processing) PO is mixed with a relatively large amount of water and processed at the nearsupercritical or supercritical phase. At $647.096 \mathrm{~K}$ and $217.755 \mathrm{MPa}$ water becomes an incompressible supercritical fluid [39]. Hot compressed water (HCW) or high temperature water (HTW) are often used to describe both sub and supercritical water. Changes in the physical and chemical properties of $\mathrm{HCW}$ become very apparent at around $300^{\circ} \mathrm{C}$, at which the density and polarity of HCW is similar to acetone, a polar organic solvent. This makes HCW a good solvent for the solvation of non-polar organic compounds in $\mathrm{PO}$, and provides a single phase medium for upgrading. It is widely observed that at these conditions water exhibits distinct processing advantages such as enhanced and tunable properties (e.g. solubility, solvent polarity, transport properties), and ease of solvent removal [40]. Other advantages of this technology include avoiding phase change and parasitic energy losses due to high-pressure processing, versatile chemistry to existing chemical and fuel infrastructure, enhanced reaction rates [41], and minimal hydrogen consumption [42]. Hydrothermal processing can also be used to generate hydrogen and $\mathrm{CO}_{2}$ as the co-product [43]. The combination of both hydrothermal and hydrodeoxygenation upgrading in an integrated process is an attractive approach

The present paper proposes a novel integrated process for pyrolysis oil upgrading based on synergies of hydrothermal and hydrodeoxygenation processes. In the proposed new process the separated water soluble pyrolysis oil is used for hydrogen generation. A second stage hydrodeoxygenation unit then follows where the water insoluble fraction is upgraded to biofuels. While reforming the water soluble phase of bio-oil has been an active research area $[44,45]$, the contribution of the present research is to propose an integrated configuration in which the hydrothermal treatment can be considered both in parallel as well as in series to the hydrodeoxygenation reactors to allow more flexibility. This configuration is also in contrast to previous studies where an external source of hydrogen or a fraction of crude bio-oil was used for hydrogen production. In the following, firstly, the experimental results for hydrodeoxygenation with nanosulphide catalysts and hydrothermal processing without catalyst are presented. The 
This article should be cited as: Sharifzadeh $M^{*}$, Richard CJ, Liu K, Hellgardt K, Chadwick D, Shah N. (2015). An integrated process for biomass pyrolysis oil upgrading: the synergistic approach. Biomass \& Bioenergy. 76, 108-117, (Link).

hydrodeoxygenation was done at conditions appropriate for a first stage slurry phase treatment leading to aqueous phase separation with only a small extent of deoxygenation. Further downstream deeper hydrodeoxygenation was included in the process scheme with details from ref [46]. Based on the experimental results, preliminary studies were conducted in order to estimate key process indicators (KPIs) for each technology in terms of mass and energy balances and hydrogen requirements. Based on these preliminary studies, a new integrated upgrading process was developed which exploits the advantages of both technologies in order to enhance process profitability. A whole-process approach was applied in order to quantify the advantages of process integration. The features of interest included process description, detailed economic analysis and sensitivity analyses. It is shown that the novel integrated process where the water soluble phase is applied for hydrogen production provides the most economic option for PO upgrading.

\section{Material and methods}

The following sections will discuss the experimental program regarding pyrolysis oil hydrodeoxygenation and hydrothermal treatment. Another feature of interest is preliminary evaluation of key process indicators, which enables proposition of an integrated process based on the synergies of the studied upgrading technologies. This section also explains the modelling and costing methods applied for techno economic analysis of the proposed process.

\subsection{Experimental studies}

The pyrolysis-oil studied was derived from Norwegian spruce, Abis Picea, supplied by Future Blends Ltd. It contained aliphatic functionalities and phenolic residues, the latter being typically derived from lignin, which is an important structural component in all woody biomass [47], Elemental analysis and water content of the pyrolysis oil is given in Table 1. Analaysis by quantitative ${ }^{31} \mathrm{P}-\mathrm{NMR}$ [48] showed that hydroxyl groups comprised $58 \%$ of the organo-oxygen, of which aliphatic $\mathrm{OH}$ was $69 \%$ of the organo- $\mathrm{OH}$. 
This article should be cited as: Sharifzadeh $\mathrm{M}^{\star}$, Richard CJ, Liu K, Hellgardt K, Chadwick D, Shah N. (2015). An integrated process for biomass pyrolysis oil upgrading: the synergistic approach.

Biomass \& Bioenergy. 76, 108-117, (Link).

The pyrolysis oil was subject to upgrading by hydrothermal treatment and hydrodeoxygenation. The experimental details and a complete set of results are tabulated in the ESM.

\subsubsection{Hydrothermal upgrading (HTU)}

Hydrothermal upgrading was conducted in sealed stainless steel tubular batch reactors $\left(8 \mathrm{~cm}^{3}\right)$ at $380^{\circ} \mathrm{C}$ using a water to pyrolysis oil ratio of 3 . The hydrothermal upgrading was carried out in the absence of catalysts. A reduced density of 1.0 was chosen for the upgrading because it is well above $\rho_{r}=0.3$ which was reported to be the minimum value at which a model oil would be soluble in HCW [49]. (Reduced density was estimated by the equation: $\rho_{r}=\rho_{w} / \rho_{w, c} ;\left(\rho_{w}=\right.$ mass of water/reactor volume), where $\rho_{\mathrm{w}, \mathrm{c}}=375 \mathrm{~kg} \mathrm{~m}^{-3}$ is the value of pure supercritical water [10]. The reaction temperature of $380^{\circ} \mathrm{C}$ was used because this was the temperature at which the $\mathrm{CH}_{3} \mathrm{O}$ - bond in guaiacol was reported to hydrolyse to give catechol and methanol [50]. The dielectric constant at the autogenic pressures generated by $\mathrm{HCW}$ at $380^{\circ} \mathrm{C}$, would be sufficient to stabilise any reaction intermediates formed in ionic reactions [39], [49]. Additionally, the ionic product of HCW increases threefold from $10^{-13.99}$ to $10^{-11.30}$ in the direction of 25 to $300^{\circ} \mathrm{C}$ [39], [49]; this means that near supercritical HCW can enhance the cleavage of C-O bonds by acid and base catalysed reactions [51]. The products from hydrothermal upgrading the pyrolysis oil were phase-separated. The water soluble pyrolysis oil (WSPO) was easily separated. The water insoluble PO was dissolved in acetone for characterization. Elemental analysis of the water insoluble PO is given in Table 2. The reduction of the oxygen content compared to the original pyrolysis oil means that less hydrogen is needed for the second-stage hydrodeoxygenation.

Table 2 should be inserted here

Gas yields were very low, especially at short residence times (Table S2 in ESM). Hydrogen can react with oxygen to give water, and insoluble hydrocarbons. However the absence of catalyst and a relatively mild reaction temperature of $380^{\circ} \mathrm{C}$ did not give sufficient hydrogen production, to remove the oxygenates in HCW [51-53]. 
This article should be cited as: Sharifzadeh $\mathrm{M}^{\star}$, Richard CJ, Liu K, Hellgardt K, Chadwick D, Shah N. (2015). An integrated process for biomass pyrolysis oil upgrading: the synergistic approach.

Biomass \& Bioenergy. 76, 108-117, (Link).

Total organic carbon (TOC) analysis of the separated water from the upgraded pyrolysis oil, showed that when the reactor is cooled immediately after reaching $380^{\circ} \mathrm{C}$, about $40 \%$ of the carbon in the original PO will be associated with components which are water soluble (Table S3 in ESM). The nature of water soluble organic oxygenates were determined by GC-MS (Table S6 in ESM). The high solubility of these components was due to hydrophilic alcoholic $\mathrm{OH}$, carbonyl $\mathrm{C}=\mathrm{O}$ and acidic $\mathrm{COOH}$ functionalities. This percentage of these functionalities was observed to decrease with residence time as they were converted to water insoluble pyrolysis oil (WIPO), char, and light gases (Table S2 in ESM). The results suggest that short residence time hydrothermal upgrading is an efficient method to extract oxygenated components from the carbon rich water insoluble phase.

\subsubsection{Hydrodeoxygenation (HDO)}

The hydrodeoxygenation of pyrolysis oil carried out in a Parr $100 \mathrm{~cm}^{3}$ stainless steel autoclave with purpose-made glass liner at $250^{\circ} \mathrm{C}$ and a hydrogen pressure (cold) of $5 \mathrm{MPa}$. Dodecane was used as solvent in a constant oil/solvent weight ratio $=0.5$. Sulphur with a mass fraction of $10^{-4}(100 \mathrm{ppm})$ was added to the reaction mixture using dibutyl disulphide as a precursor. Under the reaction conditions dibutyl disulphide is expected to be rapidly converted to $\mathrm{H}_{2} \mathrm{~S}$.

Mo and $\mathrm{Ni}$ nanosulphide catalysts were produced in situ in the autoclave at $300^{\circ} \mathrm{C}$ using metal precursor compounds dissolved in the hydrocarbon solvent containing the required amount of dibutyl disulphide. Mo naphthenate and Ni naphthenate were used as the precursors to give mass fractions of $2 \times 10^{-3}(2000 \mathrm{ppm}) \mathrm{Mo}$ and $4.9 \times 10^{-3}(490 \mathrm{ppm}) \mathrm{Ni}$ in the final hydrodeoxygenation reaction mixture corresponding to a $\mathrm{Ni} / \mathrm{Mo}$ mole ratio of 0.4 . Under these conditions the resulting $\mathrm{MoS}_{2}$ catalyst particles were determined by previous TEM studies to be typically $8 \mathrm{~nm}$ in size with limited stacking of 3 to 4 layers. The released H2S was purged from the autoclave by N2 prior to addition of the pyrolysis oil and remainder of the solvent.

The hydro-deoxygenated pyrolysis oil separated easily into a water soluble phase and a water insoluble (oil/solvent) phase. The amount of residue or coke formation was small. Gas yields were 
This article should be cited as: Sharifzadeh $\mathrm{M}^{\star}$, Richard CJ, Liu K, Hellgardt K, Chadwick D, Shah N. (2015). An integrated process for biomass pyrolysis oil upgrading: the synergistic approach.

Biomass \& Bioenergy. 76, 108-117, (Link).

also small. The results of upgrading are summarised in Table 3. The compounds present in the water soluble phase and the water insoluble phase were analysed by GC-MS (Table S8 ESM).

Table 3 should be inserted here

The high concentration of carbon in the recovered water soluble phase suggests that a significant fraction of organo-OH compounds dissolve in the water rather than undergo HDO. The organocompounds present in the water soluble phase were analysed by GC-MS. The most significant compounds were acids, mainly acetic with some C4 and C5 acids (Table S7, ESM). This suggests that at the reaction conditions there is some degree of parallel hydrothermal treatment possibly catalysed by the nanosulphide catalysts or derivatives thereof. ICP analysis of the recovered water soluble phase (ESM) did not detect any significant amount of Ni or Mo. It is assumed therefore that the catalysts remain associated with the residue

\subsection{Process design and economic evaluation}

The major part of the research involved process modelling and economic analysis. Firstly, the key indicators of hydrothermal upgrading and hydrodeoxygenation processes were identified using simplified process modelling. These preliminary studies enabled proposition of an integrated process with enhanced economic performance, and was modelled and studied in detail. Finally, the paper concludes with the results and discussions.

\subsubsection{Preliminary process modelling and evaluation}

The aforementioned experimental results were firstly applied for preliminary process modelling. The simplified process flow diagrams are shown in Figs. 1a and 1b, and discussed below.

Fig. 1 should be inserted here.

In the hydrodeoxygenation process, the solvent were mixed with the nano-catalysts precursors and sulphiding agent (Mo-Naph, Ni-Napt, DDS) in the solvent preparation vessel. Only an n-hydrocarbon, $\mathrm{n}$-dodecane, was considered as solvent. $\mathrm{H}$-donor solvents such as tetralin, did not result in significant improvement in the product yields and offer little advantage for the dispersed nanocatalysts, and is 
This article should be cited as: Sharifzadeh $\mathrm{M}^{\star}$, Richard CJ, Liu K, Hellgardt K, Chadwick D, Shah N. (2015). An integrated process for biomass pyrolysis oil upgrading: the synergistic approach. Biomass \& Bioenergy. 76, 108-117, (Link).

significantly more expensive than $n$-hydrocarbons. The catalyst-carrying solvent is then mixed with the PO at the mass ratio of 2.14:1. Hydrogen was directly injected to the slurry reactor. By comparison, in the hydrothermal upgrading, the PO is mixed with the water at the mass ratio of 1:2.98 and fed to the reactor at temperature of $380^{\circ} \mathrm{C}$. The autogenic pressure was not measured directly but was estimated to be $22 \mathrm{MPa}$. The choice of solvent ratios was based on earlier studies in hydrothermal processing [48]. No catalyst was used in the hydrothermal upgrading studies.

In both upgrading processes, the effluents of the first-stage upgrading process are phase-separated. The water insoluble pyrolysis oil (WIPO) is sent to the second-stage hydrodeoxygenation, while the water soluble pyrolysis oil (WSPO) is sent to the reformers for hydrogen production. These simplified models enable calculating several important key process indicators, shown in Table 4. These indicators suggest that the hydrodeoxygenation process features the highest fuel yield of $65.2 \%$. However, this process suffers from a hydrogen deficit and produces only $40 \%$ of its hydrogen requirements. By comparison, the process with first-stage hydrothermal upgrading does not produce significant fuel but features a large hydrogen surplus. These observations suggest that by integrating the two hydrothermal and hydrodeoxygenation technologies, it is possible to design a process which is self-sufficient and does not require any external source of hydrogen. The new process is shown in Fig. 2. The crude PO is split between the two first-stage reactors. $31.85 \%$ of the initial crude PO is sent to the hydrothermal upgrading reactor and the rest was processed in the hydro-treatment reactors. The split ratio (i.e., 0.3185 ) was optimized so the hydrogen production meets the hydrodeoxygenation requirements and the overall process is self-sustained. The effluents of both reactors are cooled and phase separated. The water insoluble pyrolysis oil in addition to the solvent are sent to the second-stage hydrodeoxygenation reactor. The water soluble pyrolysis oil is sent for hydrogen production to Section 500 of the process. 
This article should be cited as: Sharifzadeh $\mathrm{M}^{\star}$, Richard CJ, Liu K, Hellgardt K, Chadwick D, Shah N. (2015). An integrated process for biomass pyrolysis oil upgrading: the synergistic approach. Biomass \& Bioenergy. 76, 108-117, (Link).

229

230

231

232

233

234

235

236

237

238

\subsubsection{Detailed process modelling}

Fig. 3 shows the overall process block diagram. The biomass is first fed into the Pyrolysis Section (100), where it is converted to PO. The PO is then sent to the Upgrading Section (200). As discussed earlier, the upgrading section exploits two parallel first-stage reactors and will benefit from the desirable aspects of hydrothermal upgrading as well as hydrodeoxygenation technologies. The water insoluble PO is later upgraded in the second-stage hydrodeoxygenation reactor for complete hydrodeoxygenation. The upgraded PO is send to Separation Section (300) where it is resolved to gasoline and diesel products. In addition, the solvent is separated and recycled to the upgrading section. Furthermore, Section 300 is integrated to a hydrocracking reactor (Section 400), where heavy-ends are cracked into lighter higher-value products. The water soluble pyrolysis oil (WSPO) from Upgrading Section (200) is fed to the Hydrogen Production Section (500), which supplies the hydrogen required by hydro-treatment and hydrocracking reactors. All the sub-processes (100-500) were modelled in detail. The process descriptions and applied modelling techniques are reported in the Electronic Supplementary Material (ESM). The results of detailed process models were applied for calculating the operating costs and purchased equipment costs, needed for the economic analysis, as discussed later.

Fig. 3 should be inserted here.

\subsection{Economic evaluation}

The process throughput was considered to be 2000 ton per day of biomass on a dry basis, similar to a previous study by DOE [46]. In order to evaluate the economic performance of the new process, minimum fuel selling price (MFSP) was calculated, and compared to the benchmarks from literature [46]. In order to calculate the MFSP, the net present value of the project was calculated. The operating costs were evaluated based on the mass and energy balances from process simulator. In addition, the purchased and installed equipment costs of conventional unit operations were 
This article should be cited as: Sharifzadeh $\mathrm{M}^{\star}$, Richard CJ, Liu K, Hellgardt K, Chadwick D, Shah N. (2015). An integrated process for biomass pyrolysis oil upgrading: the synergistic approach. Biomass \& Bioenergy. 76, 108-117, (Link).

evaluated using Aspen Economic Analyzer ${ }^{\mathrm{TM}}$. However for the case of nonconventional equipment such as reformers, the costs were calculated with respect to data from the literature [46]:

$$
\text { New cost }=\text { Base cost } *\left(\frac{\text { New size }}{\text { Base size }}\right)^{f_{\text {scale }}}
$$

Given the total purchased equipment costs (TPEC), the total indirect costs (TIC) can be estimated by summing the value of the engineering costs ( $32 \%$ of TPEC), construction costs ( $34 \%$ of TPEC), legal and contractors fees ( $23 \%$ of TPEC) and project contingency ( $37 \%$ of TPEC). The fixed capital investment $(\mathrm{FCl})$ is the sum of Total Direct Installed Costs (TDC) and TIC. The total capital costs include $\mathrm{FCl}$ and land cost (6\% of TPEC) and the working capital (5\% $\mathrm{FCl}$ ) [46]. The variable operating costs including raw materials, utilities, and waste disposal charges are summarized in Table 5. The fixed operating costs including labour, overheads ( $95 \%$ of labour cost), maintenance ( $4 \%$ of $\mathrm{TCl})$, and insurance (4\% of $\mathrm{TCl}$ ) are scaled up based on Philipp, et al.'s study [55]. In the absence of economic data, it was assumed that the new catalyst costs $7 \%$ of the final fuel product. This is a conservative assumption because firstly, the hydrothermal reactor does not require any catalyst. Secondly, the hydrodeoxygenation catalyst is a dispersed nanoparticle type which does not require a catalyst support. Furthermore, due to the enhanced transport and heat transfer properties significantly less catalyst is needed.

\section{Table 5 should be inserted here}

The NPVs were calculated using a discounted cash flow method ( $10 \%$ discount rate) for a period of 20 years, which is the assumed plant lifetime. The plant was assumed to be $100 \%$ equity with 2.5 years as a construction period and 6 months as the start-up time. All costs in this study were indexed to the reference year of 2012. The MPSPs refers the product price at which the net present value of the project is zero at a set discounted rate of $10 \%$. The fuel price is defined as the weighted average of gasoline (42.8\%) and diesel (57.2\%) prices. The price of petroleum-derived fuel [58] was used to adjust all other fuel prices from literature to the reference year of 2012. 
This article should be cited as: Sharifzadeh $M^{*}$, Richard CJ, Liu K, Hellgardt K, Chadwick D, Shah N. (2015). An integrated process for biomass pyrolysis oil upgrading: the synergistic approach. Biomass \& Bioenergy. 76, 108-117, (Link).

277

278

\section{Results and discussions}

The following sections present and discuss the results of the technoeconomic analysis of the proposed process. The features of interest are minimum fuel selling price and its comparison with competitive scenarios and sensitivity analysis of the results with respect to underlying modelling and economic assumptions.

\subsection{Minimum Fuel selling Prices (MFSP)}

Fig. 4 shows the results of the economic analysis. The minimum fuel selling price (MFSP) is compared with three benchmark prices from the literature. They are fuel price when hydrogen is produced from reforming natural gas [46], fuel price when the bio-process in integrated to a conventional refinery [46], and the price of petroleum-derived fuel [58]. While comparison with petroleumderived fuels is illustrative for potential commercialization of the proposed technology, such comparison is subject to uncertainties in the volatile energy market. Fig 4 shows that the MFSP of $428 \$ \mathrm{~m}^{-3}$ (equivalent to $1.62 \$ /$ Gallon) in the proposed process outperforms all these benchmarks. The reason is that in the proposed process, by optimizing ratio between the two upgrading technologies (i.e., HDO \& HTU), the yield of final fuel is maximized, the hydrogen consumption is minimized and only low quality materials are used for hydrogen production.

In order to evaluate the robustness the calculated MFSP with respect to the important model parameters, a set of sensitivity analyses were conducted. Figs. 5 and 6 report the result of these analyses. Fig 5 shows the sensitivity of the MFSP with respect to working capital, $1^{\text {st }}$ stage HTU yield, catalysts price, income tax $1^{\text {st }}$ stage HDO, the fraction of pyrolysis oil needed to be processed in HTU (which represents the overall hydrogen requirement), and biomass price. In the present research, an equilibrium yield of hydrogen was assumed. However, coke formation is reported to reduce the hydrogen yield and catalyst life depending on the steam-to-carbon ratio, catalyst, and temperature $[59,60]$. The sensitivity of the minimum fuel selling price to this assumption is analysed based on the fraction of pyrolysis oil sent to hydrothermal upgrading reactor (R-202). The implication is that if the 
This article should be cited as: Sharifzadeh $\mathrm{M}^{\star}$, Richard CJ, Liu K, Hellgardt K, Chadwick D, Shah N. (2015). An integrated process for biomass pyrolysis oil upgrading: the synergistic approach. Biomass \& Bioenergy. 76, 108-117, (Link).

302

303

304

305

306

307

308

309

310

311

312

313

314

315

316

317

318

319

actual yield of hydrogen production is less than the calculated values, more pyrolysis oil must be sent to the hydrothermal upgrading (HTU) reactor. Clearly, there remains a need for further research to find stable, efficient catalysts for the steam reforming unit.

Fig. 6 shows the effect of process scale (represented by processed biomass-tpd) on the MFSP. This figure suggests that for small-scale plants $(<500 \mathrm{tpd})$, the produced biofuel may not be economically competitive anymore.

Fig. 4 should be inserted here.

Fig. 5 should be inserted here.

Fig. 6 should be inserted here.

\subsection{Total direct installed cost and operating costs}

Figs. 7 and 8 report the direct installed costs and utility costs, in addition to the contribution of each sub-process to these costs. Fig. 7 reports that the total amount of direct installed costs is 240.3 MM\$, from which $45 \%$ was associated with hydrogen production section (500). This is because WSBO is relatively dilute resulting in larger process equipment. The second largest contribution is made by biomass pyrolysis section (100). This observation is consistent with other benchmarks e.g., [46].

Fig. 8 reports the contribution of each sub-process to the utility costs. The largest contributors to electricity costs are the Upgrading (200) and Hydrogen Production (500) Sections. The Hydrogen Production Section requires electricity for compression of the combustion air and operating the aircooler; Upgrading Section consumes electricity for pumping the reactor feeds and operating the aircooler. Steam is consumed in Separation Section (300) to provide heating duties in the distillation columns, but it is also produced in Hydrogen Production Section (500) through heat recovery from hot gases. The heating duties of reactors in Upgrading Section were supplied by the fire-heaters. The costs of cooling water were moderate and were distributed between Pyrolysis, Upgrading and Separation Sections. 
This article should be cited as: Sharifzadeh $\mathrm{M}^{\star}$, Richard CJ, Liu K, Hellgardt K, Chadwick D, Shah N. (2015). An integrated process for biomass pyrolysis oil upgrading: the synergistic approach. Biomass \& Bioenergy. 76, 108-117, (Link).

Fig. 7 should be inserted here.

Fig. 8 should be inserted here.

\section{Conclusions}

The present research studied hydrothermal upgrading and hydro-treatment of biomass pyrolysis oil. The experimental results showed very different characteristics for these two technologies. While pyrolysis oil hydrodeoxygenation gives high fuel yield, it suffers from hydrogen deficit, i.e., the amount of produced hydrogen from reforming the water soluble pyrolysis oil (WSPO) is insufficient for hydrodeoxygenation of the rest of pyrolysis oil (PO). By comparison, the fuel yield of PO hydrothermal upgrading is not significant but it has the potential for producing large amounts of hydrogen. These observations suggested that an integrated configuration utilizing the two technologies can produce the maximum fuel and would be self-sufficient with respect to the hydrogen requirement. It was shown that the proposed integrated process for PO upgrading offers several advantages: the fuel production is maximized using PO hydrodeoxygenation and hydrogen production is maximized using hydrothermal upgrading. In addition, the latter process does not require hydrogen which results in reduced hydrogen requirements. The present research also studied the economic implication of the new process. It was shown that the optimized configuration is able to reduce the costs significantly and produce the fuel at a minimum price of $428 \$ \mathrm{~m}^{-3}$. The upgrading section was found to be the largest contributor to the operating costs. In addition, due to diluted water-soluble pyrolysis oil, hydrogen production required the largest capital investment. Finally, the results of sensitivity analyses suggested that the process economy is robust to changes in the modelling parameters, and the target minimum fuel selling price is achievable.

\section{Notes}

\footnotetext{
${ }^{a}$ Centre for Process Systems Engineering (CPSE), Department of Chemical Engineering, Imperial
} College London, South Kensington, London SW7 2AZ, UK. 
This article should be cited as: Sharifzadeh $\mathrm{M}^{\star}$, Richard CJ, Liu K, Hellgardt K, Chadwick D, Shah N. (2015). An integrated process for biomass pyrolysis oil upgrading: the synergistic approach. Biomass \& Bioenergy. 76, 108-117, (Link).

351

${ }^{b}$ Department of Chemical Engineering, Imperial College London, South Kensington, London SW7 2AZ, UK.

\section{Acknowledgements}

The financial support of the Carbon Trust under the "Pyrolysis Challenge" is gratefully acknowledged. We thank Future Blends Ltd. for supplying the pyrolysis oil. We are grateful to $\mathrm{Dr}$ John Halket of Specialist Bioanalytical Services for assistance with GC-MS analysis, Mr Bavish Patel for assistance with hydrothermal experiments. This work is dedicated to the late David Penfold who was instrumental in setting up the Pyrolysis Challenge research programme under which this work was funded.

\section{References}

\section{References}

[1] Naik SN, Goud VV, Rout PK, Dalai AK. Production of first and second generation biofuels: A comprehensive review. Renew Sust Energ Rev, 2010; 14 (2): 578-97.

[2] Azeez AM, Meier D, Odermatt J, Willner T. Fast Pyrolysis of African and European Lignocellulosic Biomasses Using Py-GC/MS and Fluidized Bed Reactor. Energ Fuel, 2010; 24 (3): 2078-85.

[3] Ben H, Ragauskas AJ. NMR Characterization of Pyrolysis Oils from Kraft Lignin. Energ Fuel, $2011 ; 25$ (5): 2322-32.

[4] Ben H, Ragauskas AJ. Comparison for the compositions of fast and slow pyrolysis oils by NMR Characterization. Bioresourc Technol, 2013 Nov; 147: 577-84.

[5] Mettler MS, Vlachos DG, Dauenhauer PJ. Top ten fundamental challenges of biomass pyrolysis for biofuels. Energ Environ Sci, 2012; 5 (7): 7797-809.

[6] White JE, Catallo WJ, Legendre BL. Biomass pyrolysis kinetics: A comparative critical review with relevant agricultural residue case studies. J Anal Appl Pyrol, 2011; 91 (1): 1-33.

[7] Papadikis K, Gu S, Bridgwater AV, Gerhauser H. Application of CFD to model fast pyrolysis of 
This article should be cited as: Sharifzadeh $\mathrm{M}^{\star}$, Richard CJ, Liu K, Hellgardt K, Chadwick D, Shah N. (2015). An integrated process for biomass pyrolysis oil upgrading: the synergistic approach.

Biomass \& Bioenergy. 76, 108-117, (Link).

biomass. Fuel Process Technol, 2009; 90 (4): 504-12.

[8] Isahak WNRW, Hisham MWM, Yarmo MA, Hin TY. A review on bio-oil production from biomass by using pyrolysis method. Renew Sust Energ Rev, 2012; 16 (8): 5910-23.

[9] Motasemi F, Afzal MT. A review on the microwave-assisted pyrolysis technique. Renew Sust Energ Rev, 2013 Dec; 28: 317-30.

[10] Borges FC, Du Z, Xie Q, Trierweiler JO, Cheng $Y$, Wan $Y$, et al. Fast microwave assisted pyrolysis of biomass using microwave Absorbent. Bioresourc Technol, 2014 Mar; 156: 267-4.

[11] Akhtar J, Amin NS. A review on operating parameters for optimum liquid oil yield in biomass pyrolysis. Renew Sust Energ Rev, 2012; 16 (7): 5101-9.

[12] Sadhukhan J. Multiscale simulation for high efficiency biodiesel process intensification. In: 
This article should be cited as: Sharifzadeh $M^{*}$, Richard CJ, Liu K, Hellgardt K, Chadwick D, Shah N. (2015). An integrated process for biomass pyrolysis oil upgrading: the synergistic approach.

Biomass \& Bioenergy. 76, 108-117, (Link).

402

403

404

405

406

407

408

409

410

411

412

[18] Braimakisa K, Atsoniosa K, Panopoulos KD, Karellas S, Kakaras E. Economic evaluation of decentralized pyrolysis for the production of bio-oil as an energy carrier for improved logistics towards a large centralized gasification plant. Renew Sust Energ Rev, 2014 July; 35: $57-72$.

[19] Elliott DC. Historical Developments in Hydroprocessing Bio-oils. Energ Fuels, 2007; 21 (3): $1792-815$

[20] Huber GW, Iborra S, Corma A. Synthesis of transportation fuels from biomass: chemistry, catalysts, and engineering. Chem Rev, 2006; 106 (9): 4044-98

[21] Mortensen PM, Grunwaldt J-D, Jensen PA, Knudsen KG, Jensen AD. A review of catalytic upgrading of bio-oil to engine fuels. Appl Catal A-Gen, 2011; 407(1-2): 1-19

[22] Saidi M, Samimi F, Karimipourfard D, Nimmanwudipong T, Gates BC, Rahimpour MR. Upgrading of lignin-derived bio-oils by catalytic hydrodeoxygenation. Energ Environ Sci, 2014: 7 (1); 103-29.

[23] de Miguel Mercader F, Groeneveld MJ, Kersten SRA, Geantet C, Toussaint G, Way NWJ, et al. Hydrodeoxygenation of pyrolysis oil fractions: process understanding and quality assessment through co-processing in refinery units. Energ Environ Sci, 2011; 4 (3): 985-97.

[24] Zacher AH, Olarte MV, Santosa DM, Elliott DC, Jones SB. A review and perspective of recent bio-oil hydrotreating research. Green Chem., 2014; 16 (2): 491-515.

[25] Baker EG, Elliott DC. Catalytic upgrading of biomass pyrolysis oils. In: Soltes EJ, Milne TA, editors. Pyrolysis oils from biomass, American Chemical Society, Washington, DC. 1988, p. 883-95.

[26] Vispute TP, Zhang H, Sanna A, Xiao R, Huber GW. Renewable Chemical Commodity Feedstocks from Integrated Catalytic Processing of Pyrolysis Oils. Science, 2010; 330 (6008): 1222-7. 
This article should be cited as: Sharifzadeh $M^{*}$, Richard CJ, Liu K, Hellgardt K, Chadwick D, Shah N. (2015). An integrated process for biomass pyrolysis oil upgrading: the synergistic approach.

Biomass \& Bioenergy. 76, 108-117, (Link).

[27] McCall MJ, Brandvold TA, Elliott DC, inventors; Uop Llc., assignee. Fuel and fuel blending components from biomass derived pyrolysis oil. United States patent US 8329969 B2. 2012 Dec 11.

[28] Xiu S, Shahbazi A. Bio-oil production and upgrading research: A review. Renew Sust Energ Rev, 2012, 16 (7), 4406-14.

[29] Taarning E, Osmundsen CM, Yang X, Voss B, Andersen SI, Christensen CH. Zeolite-catalyzed biomass conversion to fuels and chemicals. Energ Environ Sci, 2011; 4 (3): 793-804.

[30] Elliot DC, Hu J, Hart TR, Neuenschwander GG, inventors; Battelle Memorial Institute, assignee. Reacting the bio-oil and hydrogen over palladium catalyst, heating; producing a liquid oil from the reaction of the bio-oil and hydrogen; bioethanol. United States patent US7425657 B1. 2008 Sep 16.

[31] Bauer L, McCall M, Boldingh E, inventors; Uop Llc., assignee. Slurry Hydroconversion of Biorenewable Feedstocks. United States Patent US8022259 B2. 2011 Sep 20.

[32] Panariti N, Del Bianco A, Del Piero G, Marchionna M. Petroleum residue upgrading with dispersed catalysts: Part 1. Catalysts activity and selectivity. Appl Catal A-Gen, 2000; 204 (2): 203-13.

[33] Bellussi, G, Rispoli, G, Landoni, A, Millini, R, Molinari, D, Montanari, E, Moscotti, D, Pollesel, P. Hydroconversion of heavy residues in slurry reactors: developments and perspectives. J Catal, 2013 Dec; 308: 189-200.

[34] Fixari B, Peureux S, Elmouchnino J, Le Perchec P, Vrinat M, Morel F. New Developments in Deep Hydroconversion of Heavy Oil Residues with Dispersed Catalysts. 1. Effect of Metals and Experimental Conditions. Energ Fuel, 1994; 8 (3): 588-92.

[35] Curtis CW, Cassell FN. Investigation of the role of hydrogen donation in thermal and catalytic coprocessing. Energ Fuel, 1988; 2 (1): 1 -8.

[36] He Z, Wang X. Hydrodeoxygenation of model compounds and catalytic systems for pyrolysis bio-oils upgrading. Catal Sustainable Energy, 2012 Oct; 1: 28-52. 
This article should be cited as: Sharifzadeh $M^{*}$, Richard CJ, Liu K, Hellgardt K, Chadwick D, Shah N. (2015). An integrated process for biomass pyrolysis oil upgrading: the synergistic approach.

Biomass \& Bioenergy. 76, 108-117, (Link).

[37] Bauer LJ, Boldingh EP, inventors; Uop Llc., assignee. Use of Supported Mixed Metal Sulfides for Hydrotreating Biorenewable Feeds. United States Patent WO2010005625 A3. 2010 Mar 4.

[38] Goudriaan F, van de Beld B, Boerefijn FR, Bos GM, Naber JE, van der Wal S, Zeevalkink JA. Progress in Thermochemical Biomass Conversion. Oxford: Blackwell Science; 2001, p. 131225.

[39] Akiya N, Savage PE. Roles of Water for Chemical Reactions in High-Temperature Water. Chem Rev, 2002; 102 (8): 2725-50.

[40] Ragauskas J, Williams CK, Davison BH, Britovsek G, Cairney J, Eckert CA, Frederick Jr WJ, Hallett JP, Leak DJ, Liotta CL, Mielenz JR, Murphy R, Templer R, Tschaplinski T. The path forward for biofuels and biomaterials. Science, 2006; 311 (5760): 484-9.

[41] Peterson AA, Vogel F, Lachance RP, Froling M, Antal, Jr MJ, Tester JW. Thermochemical biofuel production in hydrothermal media: A review of sub- and supercritical water technologies. Energ Environ Sci, 2008; 1 (1): 32-65.

[42] Serrano-Ruiz JC, Dumesic JA. Catalytic routes for the conversion of biomass into liquid hydrocarbon transportation fuels. Energ Environ Sci, 2011; 4 (1): 83-99.

[43] Goyal N, Pant KK, Gupta R. Hydrogen production by steam reforming of model bio-oil using structured Ni/Al2O3 catalysts. Int J Hydrogen Energ, 2013; 38 (2): 921-33.

[44] Jones S, Zhu Y, Anderson D, Hallen R, Elliott D, Schmidt A, et al. Process Design and Economics for the Conversion of Algal Biomass to Hydrocarbons: Whole Algae Hydrothermal Liquefaction and Upgrading. Richland: Pacific Northwest National Laboratory (PNNL); 2014 March. Report No.: PNNL-23227. Contract No.: DE-AC05-76RL01830. Sponsored by the Department of Energy.

[45] Sadhukhan J, Ng KS. Economic and European Union environmental sustainability criteria assessment of bio-oil based biofuel systems: refinery integration cases. Ind Eng Chem Res, 2011; 50 (11): 6794-808. 
This article should be cited as: Sharifzadeh $M^{*}$, Richard CJ, Liu K, Hellgardt K, Chadwick D, Shah N. (2015). An integrated process for biomass pyrolysis oil upgrading: the synergistic approach.

Biomass \& Bioenergy. 76, 108-117, (Link).

[46] Jones SB, Holladay JE, Valkenburg C, Stevens DJ, Walton CW, Kinchin C, Elliott DC, Czernik S. Production of Gasoline and Diesel from Biomass via Fast Pyrolysis, Hydrotreating and Hydrocracking: A Design Case. Richland: Pacific Northwest National Laboratory (PNNL); 2014 March. Report No.: PNNL-18284. Contract No.: DE-AC05-76RL01830. Sponsored by the Department of Energy.

[47] Milne TA, Agblevor F, Davis M, Deutch S, Johnson D. Developments in Thermal Biomass Conversion. London: Blackie Academic and Professional; 1997.

[48] Richard CJ, Patel B, Chadwick D, Hellgardt K. Hydrothermal deoxygenation of pyrolysis oil from Norwegian spruce: Picea abies. Biomass Bioenerg, 2013 Sep; 56: 446-55.

[49] Townsend SH, Abraham MA, Huppert GL, Klein MT, Paspekt SC. Solvent Effects during Reactions in Supercritical Water. Ind Eng Chem Res, 1988; 27 (1): 143-9.

[50] Lawson JR, Klein MT. Influence of Water on Guaiacol Pyrolysis. Ind Eng Chem Fundam, 1985; 24 (2): 203-8.

[51] Akgüla G, Kruse A. Influence of salts on the subcritical water-gas shift reaction. J Supercrit Fluid, 2012 June; 66: 207-14.

[52] Matsumura Y, Nonoka H, Yokura H, Tsutsumi A, Yoshida A. Co-liquefaction of coal and cellulose in supercritical water. Fuel, 1999; 78 (9): 1049-56.

[53] Arai K, Adschiri T, Watanabe M. Hydrogenation of Hydrocarbons through Partial Oxidation in Supercritical Water. Ind Eng Chem Res, 2000; 39 (12): 4697-701.

[54] Phillips S, Aden A, Jechura J, Dayton D, Eggeman T. 2007, Thermochemical Ethanol via Indirect Gasification and Mixed Alcohol Synthesis of Lignocellulosic Biomass. Golden: National Renewable Energy Laboratory (NREL); April 2007, Report No.: NREL/TP-510-41168. Contract No. DE-AC36-99-G010337. Sponsored by the Department of Energy.

[55] Natural Gas Prices [Internet]. Washington: US Energy Information Administration US Department of Energy; c2008-13 [updated 2015 Jan 30; cited 2015 Feb 7]. Available from: http://www.eia.gov/dnav/ng/ng_pri_sum_dcu_nus_a.htm 
This article should be cited as: Sharifzadeh $\mathrm{M}^{\star}$, Richard CJ, Liu K, Hellgardt K, Chadwick D, Shah N. (2015). An integrated process for biomass pyrolysis oil upgrading: the synergistic approach.

Biomass \& Bioenergy. 76, 108-117, (Link).

504

[56] Electricity Wholesale Market [Internet]. Washington: US Energy Information Administration; US Department of Energy c2001-15 [updated 2015 Feb 5; cited 2015 Feb 7]. Available from: http://www.eia.gov/electricity/wholesale/

[57] Aspen Plus software tool, V8.4. Apsen Tech.

[58] Weekly Retail Gasoline and Diesel Prices [Internet]. Washington: US Energy Information Administration; US Department of Energy c2009-14 [updated 2015 Feb 2; cited 2015 Feb 7]. Available from: http://www.eia.gov/dnav/pet/pet_pri_gnd_dcus_nus_a.htm

[59] Bimbela, F, Oliva M, Ruiz J, Garcia L, Aruzo J. Steam reforming of bio-oil fractions for syngas production and energy. Env Eng Sci, 2011; 28 (11): 757-63

[60] Seyedeyn-Azad F, Abedi J,Sampouri, S. Catalytic steam reforming of aqueous phase of biooil over Ni-based alumina supported catalysts. Ind Eng Chem Res, 2014; 53 (46): 17937-44. 
This article should be cited as: Sharifzadeh $\mathrm{M}^{\star}$, Richard CJ, Liu K, Hellgardt K, Chadwick D, Shah N. (2015). An integrated process for biomass pyrolysis oil upgrading: the synergistic approach. Biomass \& Bioenergy. 76, 108-117, (Link).

(a)

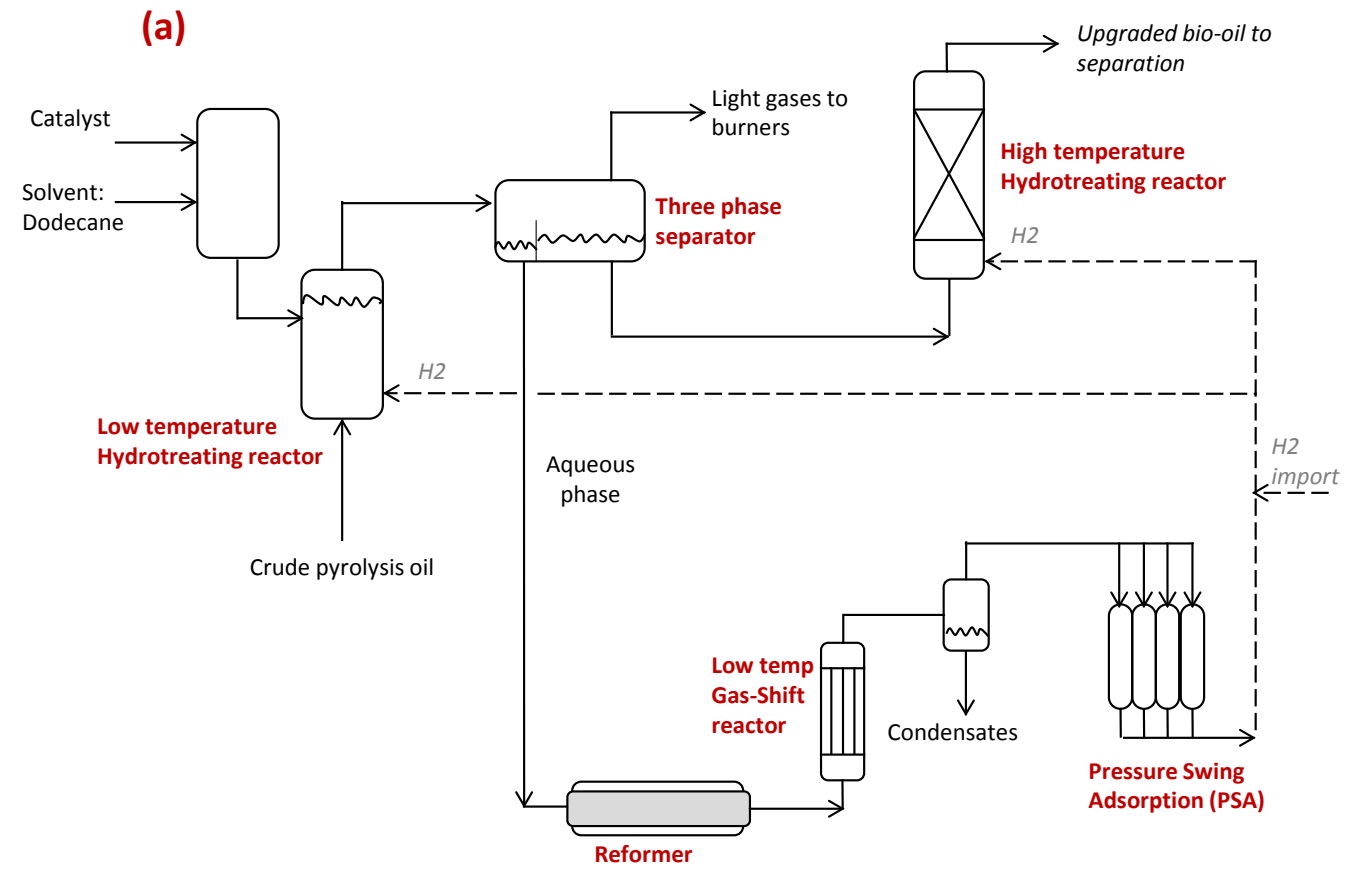

(b)

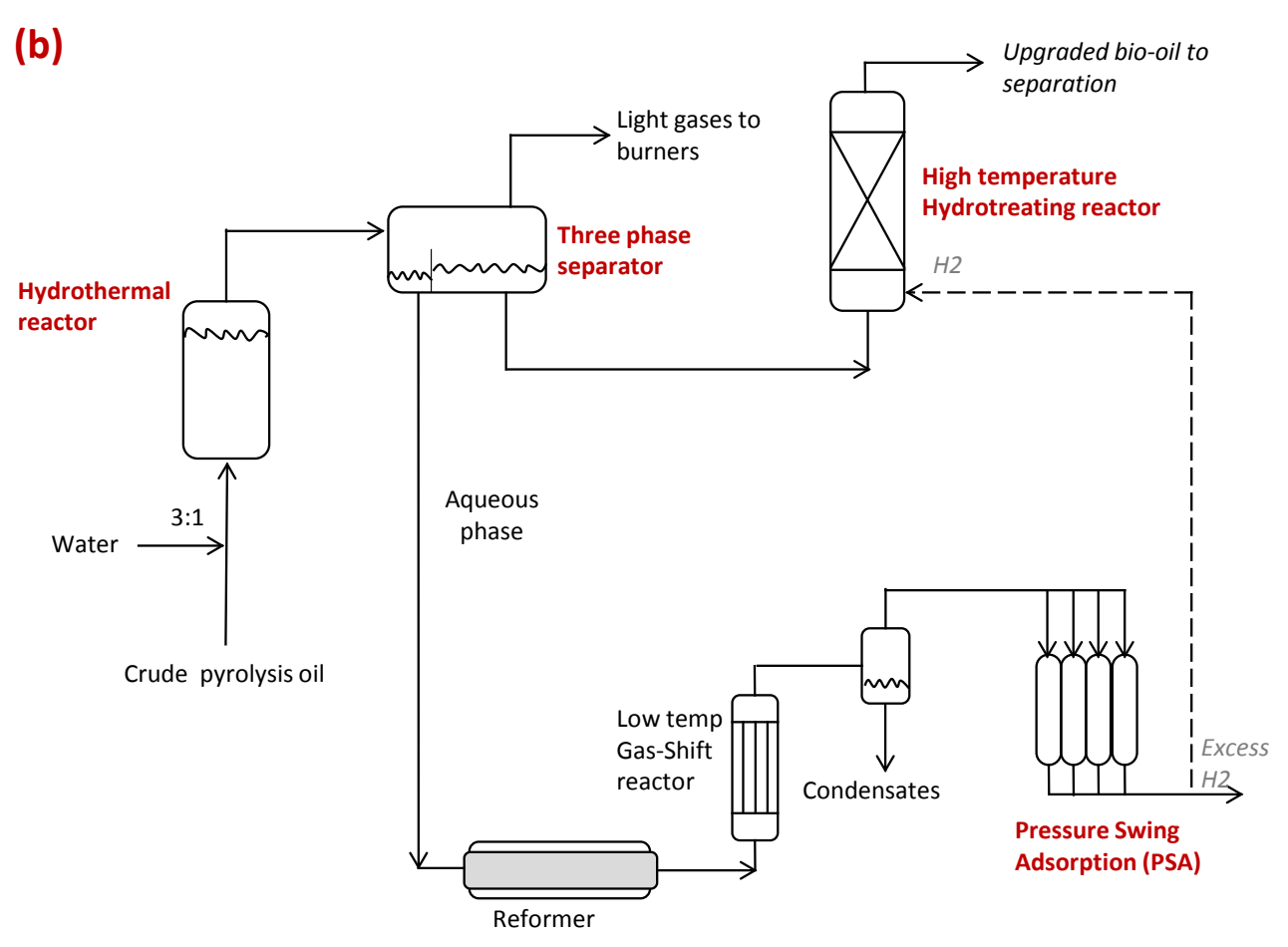

Fig. 1 - Simplified process modelling for calculating Key Process Indicators (KPIs): (a) liquid-phase 
This article should be cited as: Sharifzadeh $\mathrm{M}^{*}$, Richard $\mathrm{CJ}$, Liu K, Hellgardt K, Chadwick D, Shah N. (2015). An integrated process for biomass pyrolysis oil upgrading: the synergistic approach. Biomass \& Bioenergy. 76, 108-117, (Link).

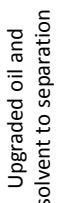

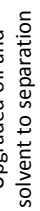
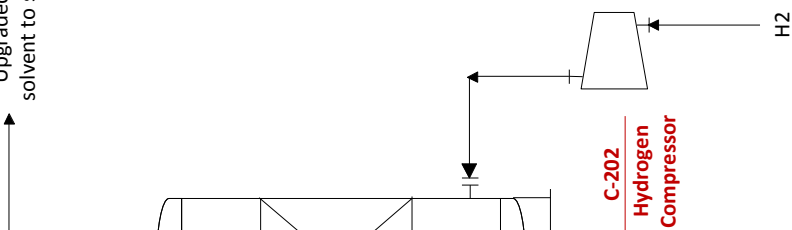

今.

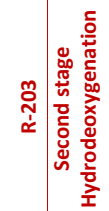
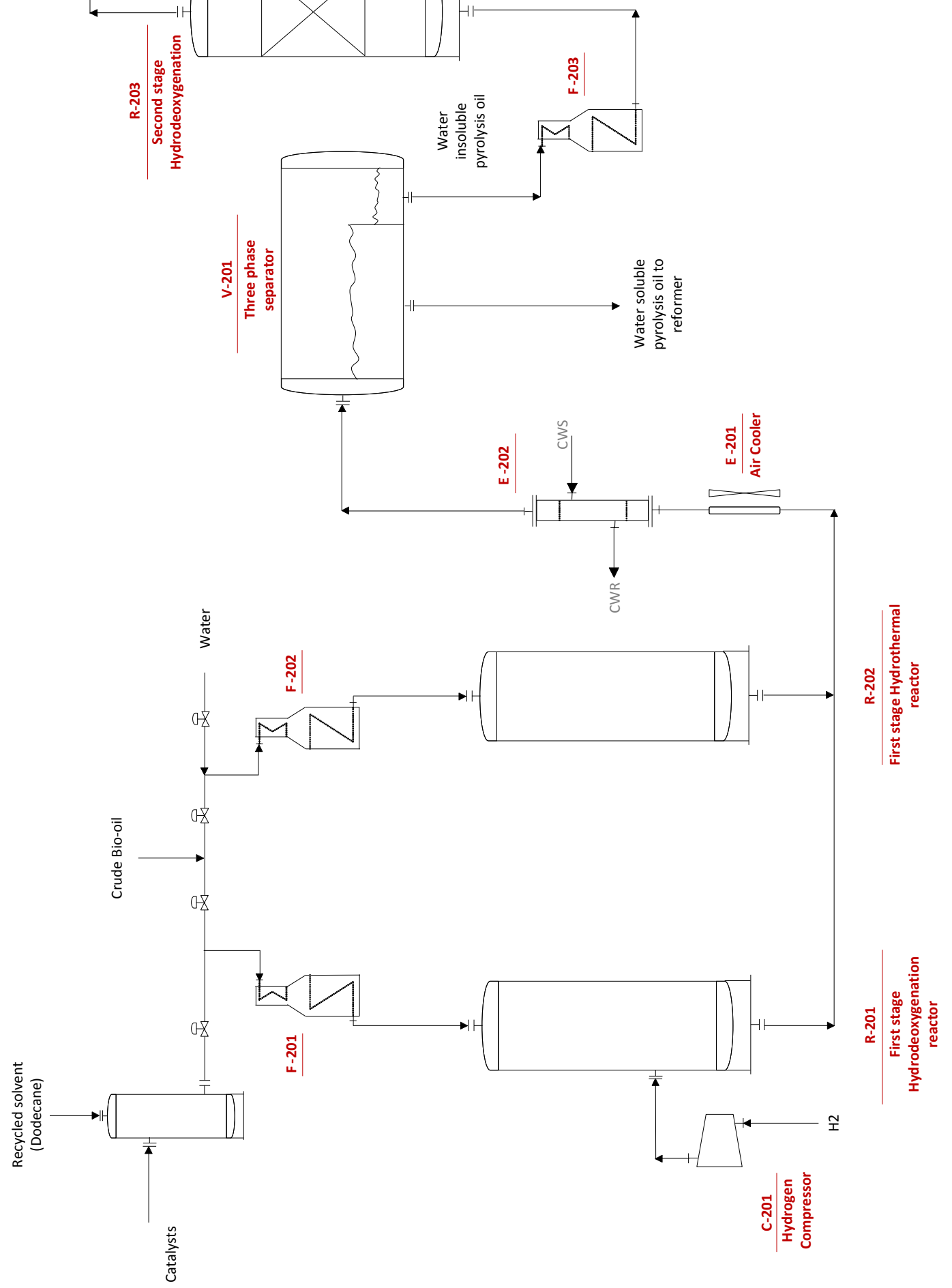
This article should be cited as: Sharifzadeh $M^{*}$, Richard CJ, Liu K, Hellgardt K, Chadwick D, Shah N. (2015). An integrated process for biomass pyrolysis oil upgrading: the synergistic approach. Biomass \& Bioenergy. 76, 108-117, (Link).

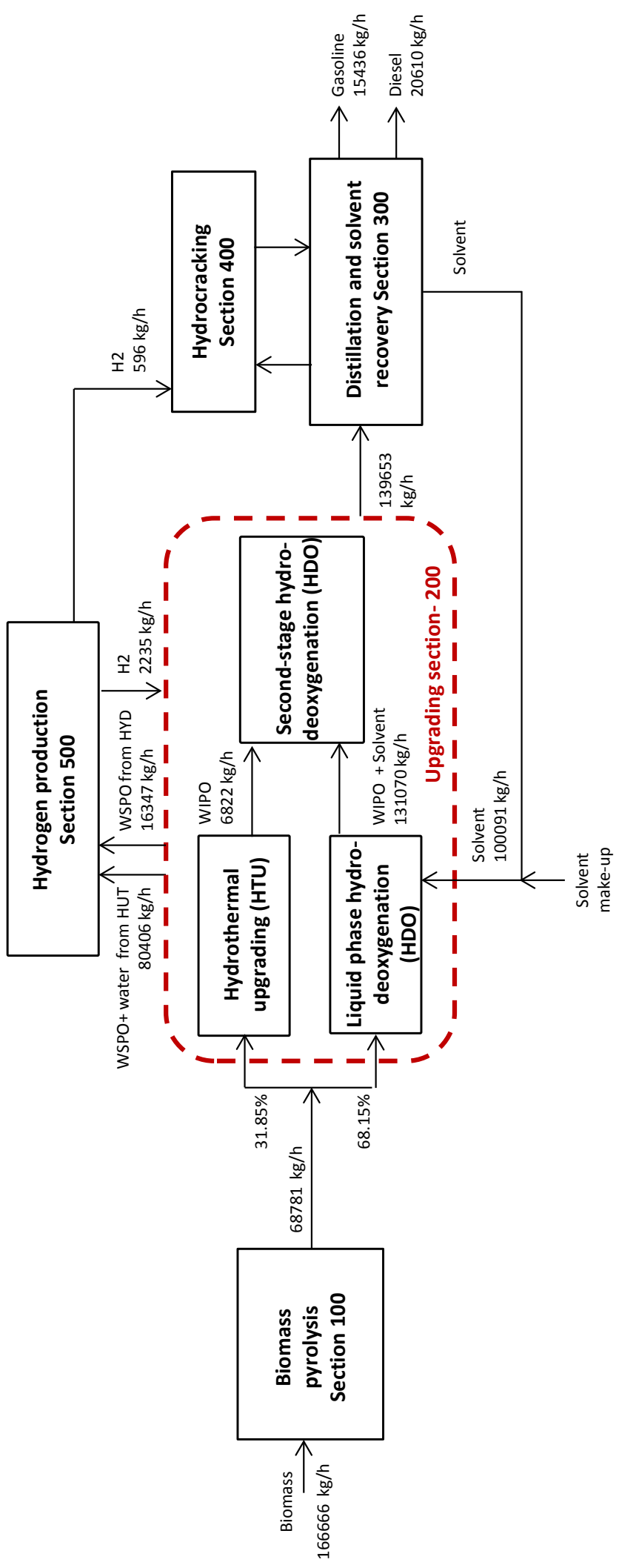


This article should be cited as: Sharifzadeh $M^{*}$, Richard CJ, Liu K, Hellgardt K, Chadwick D, Shah N. (2015). An integrated process for biomass pyrolysis oil upgrading: the synergistic approach.

Biomass \& Bioenergy. 76, 108-117, (Link).

Fig. 3 - Process block diagrams for new process including the proposed integrated upgrading

section

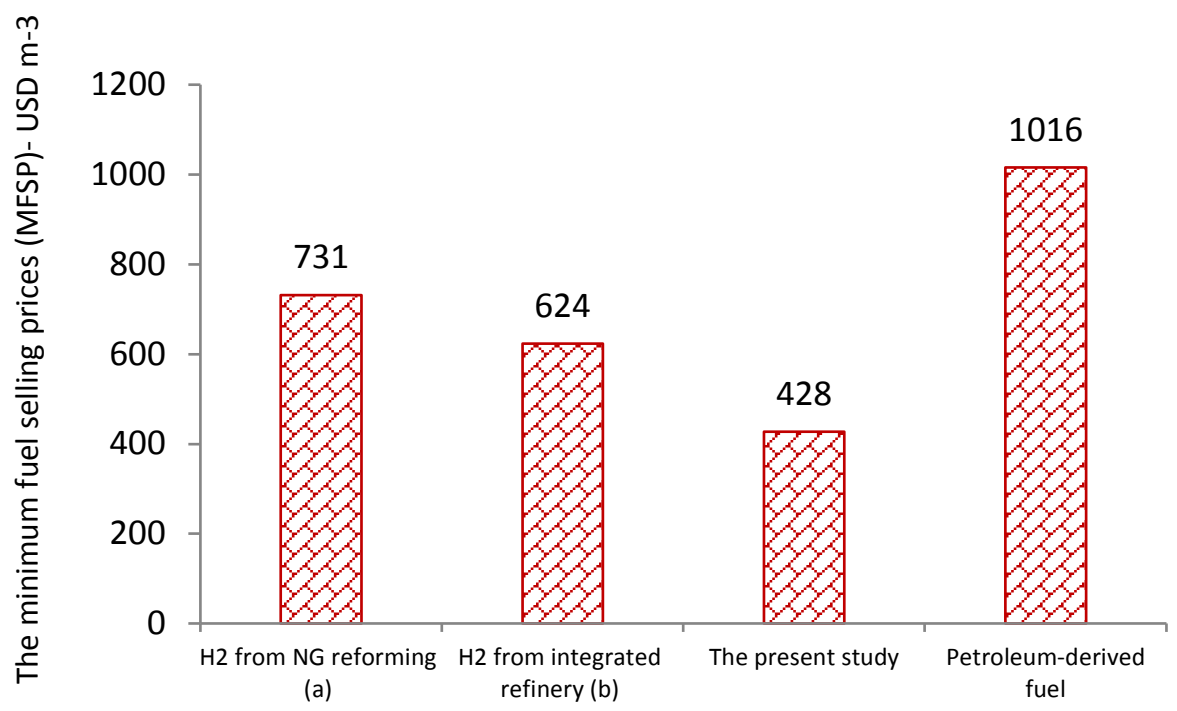

527

528 Fig. 4 - The minimum fuel selling price (MFSP), in comparison to the benchmarks from literature-

2012).

530 
This article should be cited as: Sharifzadeh $M^{*}$, Richard CJ, Liu K, Hellgardt K, Chadwick D, Shah N. (2015). An integrated process for biomass pyrolysis oil upgrading: the synergistic approach. Biomass \& Bioenergy. 76, 108-117, (Link).

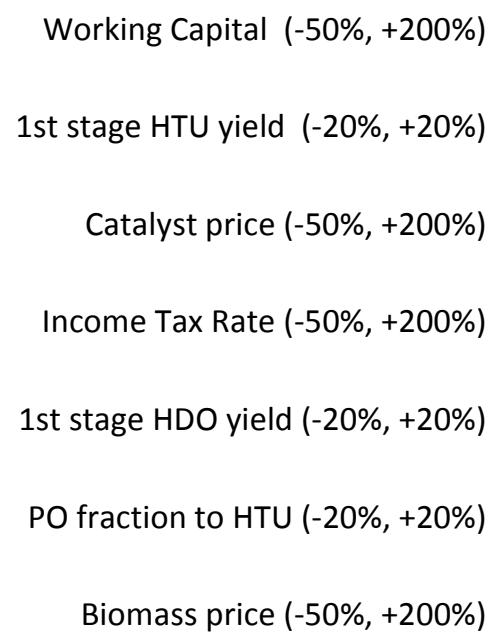

The minimum fuel selling prices (MFSP) - USD $\mathrm{m}-3$
Hight\%

$\square$ Low\% 
This article should be cited as: Sharifzadeh $\mathrm{M}^{*}$, Richard CJ, Liu K, Hellgardt K, Chadwick D, Shah N. (2015). An integrated process for biomass pyrolysis oil upgrading: the synergistic approach. Biomass \& Bioenergy. 76, 108-117, (Link).

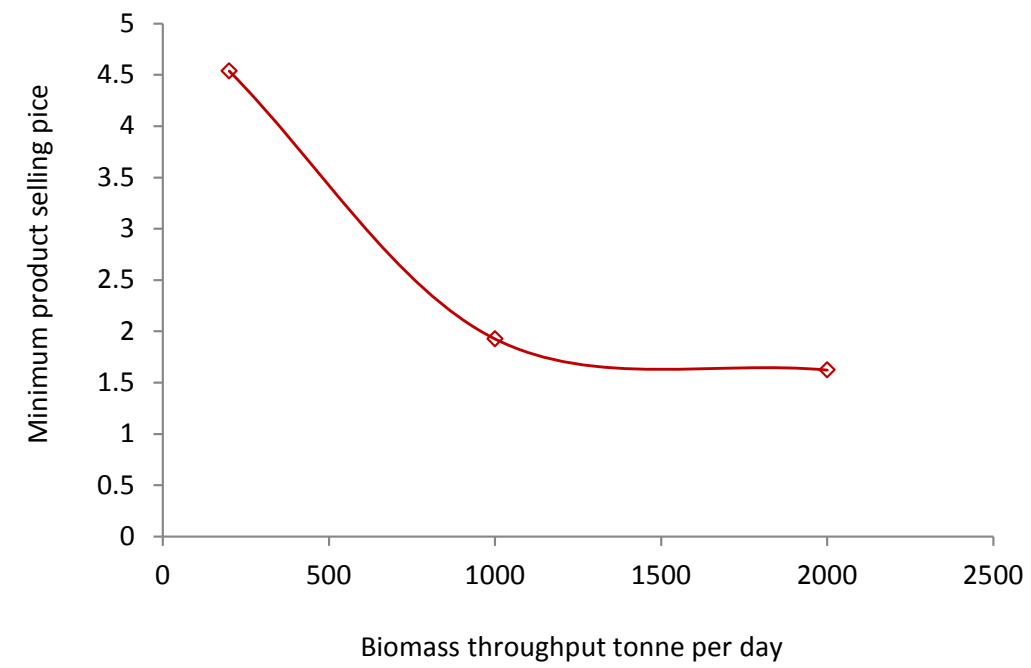


This article should be cited as: Sharifzadeh $\mathrm{M}^{\star}$, Richard CJ, Liu K, Hellgardt K, Chadwick D, Shah N. (2015). An integrated process for biomass pyrolysis oil upgrading: the synergistic approach. Biomass \& Bioenergy. 76, 108-117, (Link).

\section{Total direct installed cost $=240.29 \mathrm{M} \$$}

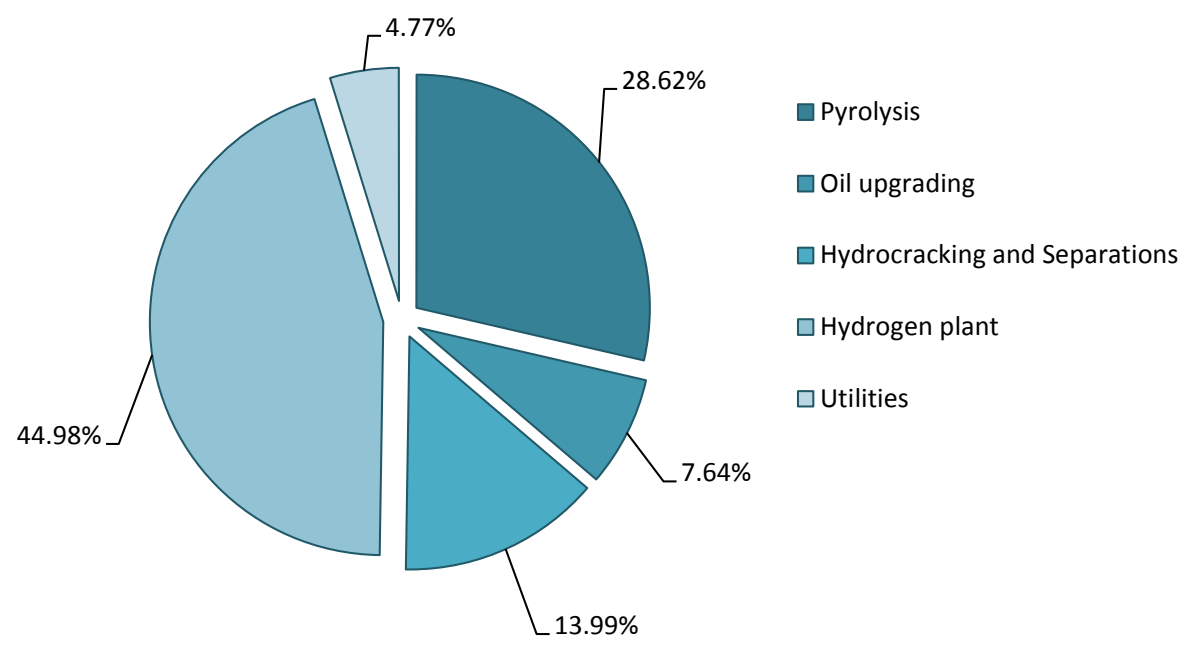

Fig. 7 - The required capital investment for different processing sections. 
This article should be cited as: Sharifzadeh $M^{*}$, Richard CJ, Liu K, Hellgardt K, Chadwick D, Shah N. (2015). An integrated process for biomass pyrolysis oil upgrading: the synergistic approach. Biomass \& Bioenergy. 76, 108-117, (Link).

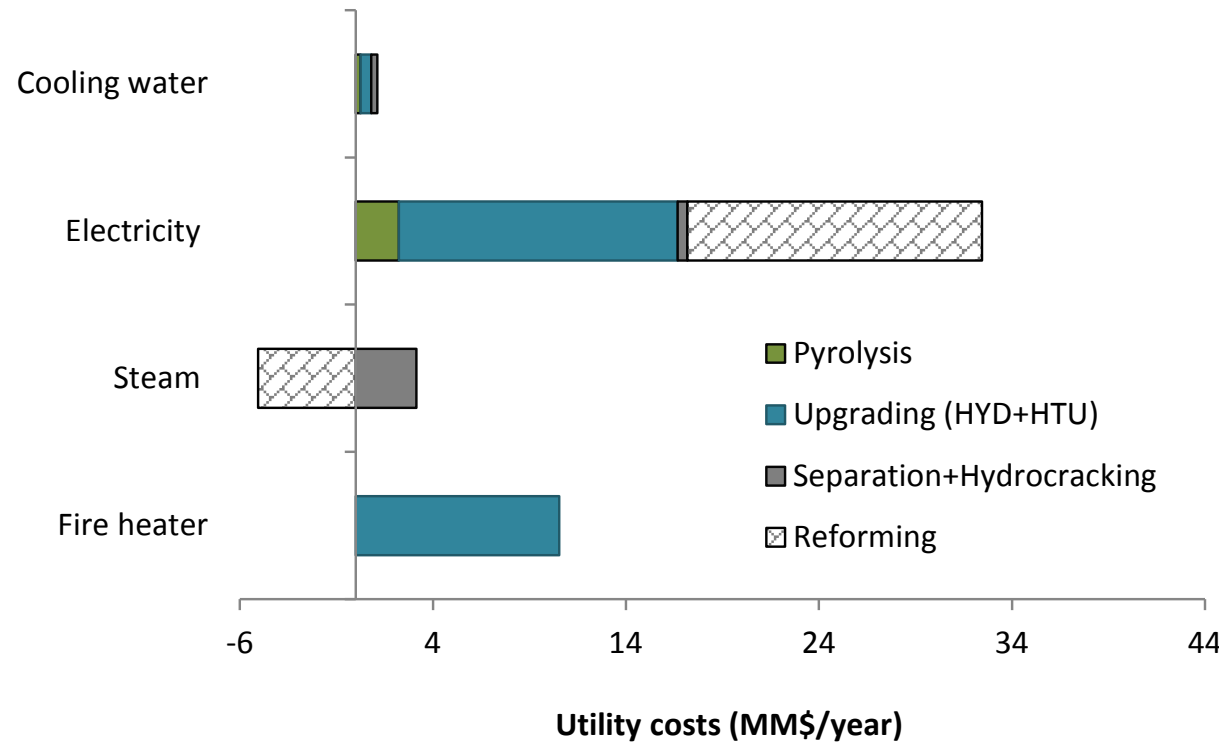

Fig. 8 - The contribution of the sub-processes to the costs of utilities. 
This article should be cited as: Sharifzadeh $M^{*}$, Richard CJ, Liu K, Hellgardt K, Chadwick D, Shah N. (2015). An integrated process for biomass pyrolysis oil upgrading: the synergistic approach. Biomass \& Bioenergy. 76, 108-117, (Link).

\section{Table 1. Composition of pyrolysis oil (mass fraction)}

$\begin{array}{llll}\text { C } & \text { H } & \text { O } & \text { Water }\end{array}$

548 
This article should be cited as: Sharifzadeh $M^{*}$, Richard CJ, Liu K, Hellgardt K, Chadwick D, Shah N. (2015). An integrated process for biomass pyrolysis oil upgrading: the synergistic approach. Biomass \& Bioenergy. 76, 108-117, (Link).

Table 2. Elemental analysis of water insoluble bio oil from hydrothermal processing at $380^{\circ} \mathrm{C}$

\begin{tabular}{llll} 
Time $^{\mathrm{a}}(\mathrm{min})$ & $\mathbf{C}$ (mass fraction) & $\mathbf{H}$ (mass fraction) & $\mathbf{O}$ (mass fraction) \\
\hline 0 & 0.63 & 0.07 & 0.30 \\
\hline 1 & 0.66 & 0.07 & 0.27 \\
\hline 10 & 0.70 & 0.07 & 0.23 \\
\hline
\end{tabular}

550

${ }^{a}$ time at $380^{\circ} \mathrm{C}$; heat up time $=5 \mathrm{~min}$ 
This article should be cited as: Sharifzadeh $M^{*}$, Richard CJ, Liu K, Hellgardt K, Chadwick D, Shah N. (2015). An integrated process for biomass pyrolysis oil upgrading: the synergistic approach. Biomass \& Bioenergy. 76, 108-117, (Link).

Table 3. Hydrodeoxygenation of pyrolysis oil at $250^{\circ} \mathrm{C}$ using NiMo nanosulphide catalyst

\begin{tabular}{llll}
$\begin{array}{l}\text { Carbon in water } \\
\text { phase (mass fraction) }\end{array}$ & $\begin{array}{l}\text { Oxygen in solvent } \\
\text { phase (mass fraction) }\end{array}$ & $\begin{array}{l}\text { Oxygen in residue } \\
\text { (mass fraction) }\end{array}$ & $\begin{array}{l}\text { Estimated Organo Oxygen } \\
\text { removal (mass fraction) }\end{array}$ \\
\hline 0.113 & 0.166 & 0.277 & 0.20 \\
\hline
\end{tabular}

552 
This article should be cited as: Sharifzadeh $M^{*}$, Richard CJ, Liu K, Hellgardt K, Chadwick D, Shah N. (2015). An integrated process for biomass pyrolysis oil upgrading: the synergistic approach. Biomass \& Bioenergy. 76, 108-117, (Link).

\section{Table 4. Key process indicators (KPIs)}

\begin{tabular}{l|l|l}
\hline Key process indicators (KPIs) & HTU & HDO \\
\hline Fuel: Pyrolysis oil (mass ratio) & 0.3228 & 0.6520 \\
\hline H2 required: Pyrolysis oil (mass ratio) & 0.0117 & 0.0422 \\
\hline H2 produced : Pyrolysis oil (mass ratio) & 0.0659 & 0.0169 \\
\hline Net H2 requirement : Pyrolysis oil (mass ratio) & 0.0542 & -0.0254 \\
\hline Solvent : Pyrolysis oil (mass ratio) & 2.98 (water) & 2.14 (dodecane) \\
\hline
\end{tabular}


This article should be cited as: Sharifzadeh $M^{*}$, Richard CJ, Liu K, Hellgardt K, Chadwick D, Shah N. (2015). An integrated process for biomass pyrolysis oil upgrading: the synergistic approach. Biomass \& Bioenergy. 76, 108-117, (Link).

Table 5. Summary of variable operating cost

\begin{tabular}{|c|c|c|c|}
\hline Materials/Chemicals/Utilities & Cost & Unit & Reference \\
\hline Biomass & 0.0552 & $\$ \mathrm{~kg}^{-1}$ & [46] \\
\hline Natural gas & 0.137373309 & $\$ m^{-3}$ & [55] \\
\hline Catalyst & $7 \%$ of Fuel price & & [46] \\
\hline Electricity & 37.02 & $\$ M W^{-1}$ & [56] \\
\hline Disposal of ash & 0.0198 & $\$ \mathrm{~kg}^{-1}$ & [46] \\
\hline Steam ${ }^{a}$ & $1.9-4.5$ & $\$ G^{-1}$ & [57] \\
\hline Cooling water & 0.212 & $\$ G^{-1}$ & [57] \\
\hline
\end{tabular}

Note: ${ }^{\mathrm{a}}$ varied for steam with different pressure; $b$ varied for different types of refrigerant. 


\title{
An Integrated Process for Biomass Pyrolysis Oil Upgrading: A Synergistic Approach
}

\author{
M. Sharifzadeh ${ }^{a *}$, C. J. Richard ${ }^{b}$, K. Liü ${ }^{b}$, K. Hellgardt ${ }^{b}$, D. Chadwick ${ }^{b}$ and N. Shah ${ }^{a}$ \\ ${ }^{a}$ Centre for Process Systems Engineering (CPSE), Department of Chemical Engineering, Imperial College London. \\ ${ }^{b}$ Department of Chemical Engineering, Imperial College London
}

\section{Electronic Supplementary Material}

The presented materials include the details of the experimental procedures and summary of the results. In addition, this document report additional information regarding process modelling including the flow diagrams and descriptions of Sections 100-500 (in Fig. 3 of the manuscript), and the assumptions used for modelling each section.

\section{Experimental procedures and summary of results}

A set of five stainless steel batch reactors (volume: $8.0 \mathrm{~cm} 3$ and $12.7 \mathrm{~mm}$ bore) were used for all experiments according to a previously reported method ${ }^{[\mathrm{S} 1]}$. These were constructed of stainless steel tubing and sealed at each end using a gas sampling valve and compression fittings (Swagelok ${ }^{\circledR}$ ). The empty batch reactors were weighed initially and charged with deionised water (3g) and pyrolysis oil (1g). The batch reactors were then purged with argon to remove air, sealed and weighed a second time. They were then heated in an air recirculating oven to a reaction temperature of $380^{\circ} \mathrm{C}$. The residence times were: to $=0$ (taken as time when reaction temperature was reached) $\mathrm{t}_{1}=1 ; \mathrm{t}_{2}=2 ; \mathrm{t}_{5}=5 ; \mathrm{t}_{10}=10$ minutes. It required 5 minutes (i.e., to) to reach the reaction temperature of $380^{\circ} \mathrm{C}$. After heating to the required residence time, the batch reactors were immediately quenched in ice and left to stand for several hours to maximise any phase separation of water, gas and char. After each reaction, the loaded reactors were externally dried and then reweighed a third time to confirm no potential mass loss occurred due to leakage. Water soluble pyrolysis oil was separated, weighed and stored for analysis. The remaining oil was then washed out of the reactors with acetone and all the acetone washings stored. The acetone insoluble char was collected and weighed. Any char which could not be collected was determined by calculating the difference between the weights of the emptied initial and post reaction batch reactors. A GC-TCD was used to analyse for $\mathrm{CO}, \mathrm{CO}_{2}, \mathrm{H}_{2}$ and $\mathrm{CH}_{4}$.

Table 1 (in the manuscript) shows the elemental analysis of the pyrolysis oil. Table S1 reports the mass yield of each phase for hydrothermal experiment at different residence times. Table S2 reports the total organic carbon and carbon yield of water soluble pyrolysis oil for different residence times. The elemental analyses of water insoluble pyrolysis oil for the hydrothermal experiments are reported in Table 2 (in the manuscript) and the compositions of gas products from hydrothermal experiment are reported in Table S3. Table S4 reports the composition of the water soluble product using GCMS.

The GC-MS analysis of all samples was carried out at the Mass Spectrometry Facility at King's College London using an Agilent 6890/5973 Mass Selective Detector GC-MS equipped with a $30 \mathrm{~m} \times 0.25 \mathrm{~mm} \times 250$ $\mu \mathrm{m}$ HP-5MS column. The program parameters were $50^{\circ}(1 \mathrm{~min})-10^{\circ} / \mathrm{min}-320^{\circ}$ (10 min). 4-methyl valeric acid and tridecane were used as internal standards for the aqueous and non-aqueous fractions respectively.

CHN analysis was done at the University of Sheffield Microanalysis service using a Perkin Elmer 2400 CHNS/O Series II Elemental Analyser. The CHM analysis of each sample was the average of three determinations. The oxygen content was determined by mass balance. The results are accurate to $\pm 0.3 \%$ of the total mass of sample. TOC analysis was done by Intertek Sunbury Technology Centre (UK). Water content of the pyrolysis oil was done by Karl Fischer coulometric titration using a Mettler Toledo C20X instrument.

The experimental procedure for hydrodeoxygenation is reported in the manuscript. Table S4 reports the mass balance for the hydrodeoxygenation experiment. Table S6 reports the composition of water soluble pyrolysis oil (WSPO) in the hydrodeoxygenation experiment. Table S7 reports the composition of water insoluble pyrolysis oil (WIPO) in the hydrodeoxygenation experiment. 
Table S1. The mass balance for hydrothermal experiments

\begin{tabular}{|l|l|l|l|l|l|}
\hline Time [min] & Initial pyrolysis oil & WSBO & WIBO & Char & Gas \\
\hline $\mathrm{t} 0=0$ & 1.01 & 3.7027 & 0.31427 & 0.001 & 0 \\
\hline $\mathrm{t} 1=1$ & 1.00 & 3.6727 & 0.3354 & 0.0009 & 0.002005522 \\
\hline $\mathrm{t} 10=10$ & 1.08 & 3.6823 & 0.32143 & 0.0193 & 0.000923392 \\
\hline
\end{tabular}

Table S2. Total organic carbon and carbon yield of water soluble pyrolysis oil for different residence time for the hydrothermal experiments

\begin{tabular}{|l|l|l|}
\hline Time [min] & TOC & C in WSBO/C in PO [\%] \\
\hline $\mathrm{t} 0=0$ & 4.8 & 40.4 \\
\hline $\mathrm{t} 1=1$ & 3.8 & 32.9 \\
\hline $\mathrm{t} 2=2$ & 3.3 & 28.8 \\
\hline $\mathrm{t} 5=5$ & 3.0 & 26.3 \\
\hline $\mathrm{t} 10=10$ & 2.8 & 22.2 \\
\hline
\end{tabular}

Table S4. The composition (mass fractions) of water soluble pyrolysis oil (WSPO) analysed by GCMS for the hydrothermal experiments.

\begin{tabular}{|c|c|c|c|}
\hline \multirow{2}{*}{$\begin{array}{c}\text { Compound } \\
\text { Time (min) }\end{array}$} & \multicolumn{3}{|l|}{ Oil E } \\
\hline & $\mathrm{t} 0=5$ & $\mathrm{t} 1=6$ & $\mathrm{t} 10=15$ \\
\hline & mass fraction & mass fraction & mass fraction \\
\hline 2-Butanone, 1-hydroxy- & 0.0021 & 0.0030 & 0.0001 \\
\hline Acetic acid & 0.0222 & 0.0356 & 0.0040 \\
\hline Furfural & 0.0062 & 0.0100 & 0.0000 \\
\hline Formic acid & 0.0000 & 0.0000 & 0.0000 \\
\hline Ketone, 2-furyl methyl & 0.0000 & 0.0000 & 0.0000 \\
\hline Propanoic Acid & 0.0032 & 0.0054 & 0.0008 \\
\hline Butanoic Acid & 0.0010 & 0.0015 & 0.0002 \\
\hline Butanoic acid, 4-hydroxy- & 0.0008 & 0.0011 & 0.0001 \\
\hline 2(5H)-Furanone, 3-methyl- & 0.0016 & 0.0020 & 0.0001 \\
\hline 2-Cyclopenten-1-one, 2-hydroxy-3-methyl- & 0.0050 & 0.0070 & 0.0006 \\
\hline Guaiacol & 0.0074 & 0.0093 & 0.0001 \\
\hline trans-2-Pentenoic acid & 0.0008 & 0.0013 & 0.0000 \\
\hline 4-Methyl-5H-furan-2-one & 0.0011 & 0.0018 & 0.0001 \\
\hline p-Cresol, 2-methoxy- & 0.0055 & 0.0070 & 0.0006 \\
\hline Phenol & 0.0019 & 0.0026 & 0.0002 \\
\hline 2-Hydroxy-gamma-butyrolactone & 0.0002 & 0.0000 & 0.0000 \\
\hline Levulinic acid & 0.0023 & 0.0051 & 0.0008 \\
\hline HMF & 0.0114 & 0.0151 & 0.0000 \\
\hline Vanillin & 0.0046 & 0.0048 & 0.0002 \\
\hline Acetophenone, 4'-hydroxy-3'-methoxy- & 0.0023 & 0.0000 & 0.0000 \\
\hline Guaiacylacetone & 0.0017 & 0.0025 & 0.0000 \\
\hline Pyrocatechol & 0.0033 & 0.0043 & 0.0004 \\
\hline 4-((1E)-3-Hydroxy-1-propenyl)-2-methoxyphenol & 0.0009 & 0.0006 & 0.0000 \\
\hline Benzeneacetic acid, 4-hydroxy-3-methoxy- & 0.0032 & 0.0038 & 0.0004 \\
\hline 1,4-Benzenediol & 0.0014 & 0.0018 & 0.0002 \\
\hline Water & 0.9099 & 0.8745 & 0.9910 \\
\hline Total & 1 & 1 & 1 \\
\hline
\end{tabular}


Table S6. The composition (mass fractions) of water soluble pyrolysis oil (WSPO) analysed by GCMS for the hydrodeoxygenation experiments.

\begin{tabular}{|c|c|c|c|}
\hline Compound & CAS Number & Mol Formula & Mass fraction \\
\hline Acetaldehyde & $75-07-0$ & $\mathrm{C} 2 \mathrm{H} 4 \mathrm{O}$ & 0.00023 \\
\hline Acetone & $67-64-1$ & $\mathrm{C} 3 \mathrm{H} 6 \mathrm{O}$ & 0.00108 \\
\hline Acetic acid, methyl ester & $79-20-9$ & $\mathrm{C} 3 \mathrm{H} 6 \mathrm{O} 2$ & 0.00014 \\
\hline 2-Butanone & 78-93-3 & $\mathrm{C} 4 \mathrm{H} 8 \mathrm{O}$ & 0.00089 \\
\hline Ethanol & $64-17-5$ & $\mathrm{C} 2 \mathrm{H} 6 \mathrm{O}$ & 0.02876 \\
\hline 2,3-Butanedione & $431-03-8$ & $\mathrm{C} 4 \mathrm{H} 6 \mathrm{O} 2$ & 0.00007 \\
\hline Pentanoic acid, methyl- & $624-24-8$ & $\mathrm{C} 6 \mathrm{H} 12 \mathrm{O} 2$ & 0.00017 \\
\hline Cyclopentanone & $120-92-3$ & $\mathrm{C} 5 \mathrm{H} 8 \mathrm{O}$ & 0.00089 \\
\hline Acetoin & $513-86-0$ & $\mathrm{C} 4 \mathrm{H} 8 \mathrm{O} 2$ & 0.00741 \\
\hline 2-Propanone, 1-hydroxy- & $116-09-6$ & $\mathrm{C} 3 \mathrm{H} 6 \mathrm{O} 2$ & 0.00456 \\
\hline Propanoic acid, 2-hydroxy- & $97-64-3$ & $\mathrm{C} 3 \mathrm{H} 6 \mathrm{O} 3$ & 0.00438 \\
\hline 1-Hydroxy-2-butanone & $5077-67-8$ & $\mathrm{C} 4 \mathrm{H} 8 \mathrm{O} 2$ & 0.00266 \\
\hline Hydroxy Acetic acid & $79-14-1$ & $\mathrm{C} 2 \mathrm{H} 4 \mathrm{O} 3$ & 0.00111 \\
\hline Acetic acid & $64-19-7$ & $\mathrm{C} 2 \mathrm{H} 4 \mathrm{O} 2$ & 0.03624 \\
\hline Furfural & 98-01-1 & $\mathrm{C} 5 \mathrm{H} 4 \mathrm{O} 2$ & 0.00004 \\
\hline 2-Furanmethanol, tetra... & $97-99-4$ & $\mathrm{C} 5 \mathrm{H} 10 \mathrm{O} 2$ & 0.00235 \\
\hline Formic acid & $64-18-6$ & $\mathrm{CH} 2 \mathrm{O} 2$ & 0.00001 \\
\hline 2-Acetylfuran & $1192-62-7$ & $\mathrm{C} 6 \mathrm{H} 6 \mathrm{O} 2$ & 0.00196 \\
\hline 2,5-Hexanedione & $110-13-4$ & $\mathrm{C} 6 \mathrm{H} 10 \mathrm{O} 2$ & 0.00579 \\
\hline Propanoic acid & $79-09-4$ & $\mathrm{C} 3 \mathrm{H} 6 \mathrm{O} 2$ & 0.00480 \\
\hline Propanoic acid, 2-methyl- & $79-31-2$ & $\mathrm{C} 4 \mathrm{H} 8 \mathrm{O} 2$ & 0.00047 \\
\hline Pentanoic acid, 4-oxo-ethyl ester & $539-88-8$ & $\mathrm{C} 7 \mathrm{H} 12 \mathrm{O} 3$ & 0.00144 \\
\hline 3,6-Heptanedione & $1703-51-1$ & $\mathrm{C} 7 \mathrm{H} 12 \mathrm{O} 2$ & 0.00128 \\
\hline 1,2-Propanediol, 2-acetate & $627-69-0$ & $\mathrm{C} 5 \mathrm{H} 10 \mathrm{O} 3$ & 0.00059 \\
\hline 1,2-Ethanediol & $107-21-1$ & $\mathrm{C} 2 \mathrm{H} 6 \mathrm{O} 2$ & 0.00186 \\
\hline Butanoic acid & $107-92-6$ & $\mathrm{C} 4 \mathrm{H} 8 \mathrm{O} 2$ & 0.00744 \\
\hline 1,2-Ethanediol, monoacetate & $542-59-6$ & $\mathrm{C} 4 \mathrm{H} 8 \mathrm{O} 3$ & 0.01539 \\
\hline Butyrolactone & 96-48-0 & $\mathrm{C} 4 \mathrm{H} 6 \mathrm{O} 2$ & 0.00382 \\
\hline 2-Furanone, 2,5-dihydro-3,5-dimethyl & $35298-48-7$ & $\mathrm{C} 6 \mathrm{H} 8 \mathrm{O} 2$ & 0.00011 \\
\hline Propanoic acid, 2-hydroxy- & $503-66-2$ & $\mathrm{C} 3 \mathrm{H} 6 \mathrm{O} 3$ & 0.00124 \\
\hline 2-Butenoic acid, $(E)$ - & $107-93-7$ & $\mathrm{C} 4 \mathrm{H} 6 \mathrm{O} 2$ & 0.00003 \\
\hline Crotonic acid & $107-93-7$ & $\mathrm{C} 4 \mathrm{H} 6 \mathrm{O} 2$ & 0.00014 \\
\hline 2-Cyclopenten-1-one, 2 methyl? & $1120-73-6$ & $\mathrm{C} 6 \mathrm{H} 8 \mathrm{O}$ & 0.00005 \\
\hline 2-Pentenoic acid & 13991-37-2 & $\mathrm{C} 5 \mathrm{H} 8 \mathrm{O} 2$ & 0.00014 \\
\hline Phenol, 2-methoxy- & $90-05-1$ & $\mathrm{C} 7 \mathrm{H} 8 \mathrm{O} 2$ & 0.00948 \\
\hline 4-Methyl-5H-furan-2-one & $6124-79-4$ & $\mathrm{C} 5 \mathrm{H} 6 \mathrm{O} 2$ & 0.00081 \\
\hline Succinic anhydride & $108-30-5$ & $\mathrm{C} 4 \mathrm{H} 4 \mathrm{O} 3$ & 0.00104 \\
\hline Creosol & $93-51-6$ & $\mathrm{C} 8 \mathrm{H} 10 \mathrm{O} 2$ & 0.00518 \\
\hline Phenol, 2-methyl- & $95-48-7$ & $\mathrm{C} 7 \mathrm{H} 8 \mathrm{O}$ & 0.00102 \\
\hline Phenol & $108-95-2$ & $\mathrm{C} 6 \mathrm{H} 6 \mathrm{O}$ & 0.00361 \\
\hline Phenol, 4-ethyl-2-methoxy- & $2785-89-9$ & $9 \mathrm{H} 12 \mathrm{O} 2$ & 0.00178 \\
\hline Carvenone & $499-74-1$ & $\mathrm{C} 10 \mathrm{H} 16 \mathrm{O}$ & 0.00053 \\
\hline Valeric anhydride & 2082-59-9 & $\mathrm{C} 10 \mathrm{H} 18 \mathrm{O} 3$ & 0.00006 \\
\hline 2-HYDROXY-GAMMA-BUTYROLACTONE & $19444-84-9$ & $\mathrm{C} 4 \mathrm{H} 6 \mathrm{O} 3$ & 0.00097 \\
\hline $2(3 \mathrm{H})$-Furanone, 3-acetyldihydro & $517-23-7$ & $\mathrm{C} 6 \mathrm{H} 8 \mathrm{O} 3$ & 0.00050 \\
\hline Ethyl hydrogen succinate & $1070-34-4$ & $\mathrm{C} 6 \mathrm{H} 10 \mathrm{O} 4$ & 0.00035 \\
\hline 4-Acetylbutyric acid & $3128-06-1$ & $\mathrm{C} 6 \mathrm{H} 10 \mathrm{O} 3$ & 0.00010 \\
\hline (R)-5-Hydroxymethyldihydrofuran-2-one & $52813-63-5$ & $(\mathrm{C} 5 \mathrm{H} 8 \mathrm{O} 3)$ & 0.00752 \\
\hline 1,3-Cyclopentanedione & $3859-41-4$ & $\mathrm{C} 5 \mathrm{H} 6 \mathrm{O} 2$ & 0.00052 \\
\hline Vanillin & $121-33-5$ & $\mathrm{C} 8 \mathrm{H} 8 \mathrm{O} 3$ & 0.00016 \\
\hline Isoeugenol & $97-54-1$ & $\mathrm{C} 10 \mathrm{H} 12 \mathrm{O} 2$ & 0.00002 \\
\hline Apocynin & $498-02-2$ & $\mathrm{C} 9 \mathrm{H} 10 \mathrm{O} 3$ & 0.00430 \\
\hline 2-Cyclopenten-1-one,3-methyl? & $2758-18-1$ & $\mathrm{C} 6 \mathrm{H} 8 \mathrm{O}$ & 0.00048 \\
\hline Acetophenone, 4'-hydroxy- & 99-93-4 & $\mathrm{C} 8 \mathrm{H} 8 \mathrm{O} 2$ & 0.00014 \\
\hline Hydroquinone & $123-31-9$ & $\mathrm{C} 6 \mathrm{H} 6 \mathrm{O} 2$ & 0.00048 \\
\hline Water & & $\mathrm{H} 2 \mathrm{O}$ & 0.77938 \\
\hline Unidentified & & & 0.04403 \\
\hline
\end{tabular}


Table S3. Composition of gas products from hydrothermal experiments

\begin{tabular}{|l|l|l|l|l|l|}
\hline time $(\mathrm{min})$ & vol & $\mathrm{CH}_{4}$ & $\mathrm{H}_{2}$ & $\mathrm{CO}$ & $\mathrm{CO}_{2}$ \\
\hline & $(\mathrm{ml} / \mathrm{g}$-oil) & $(\mathrm{vol} / \mathrm{vol} \%)$ & $(\mathrm{vol} / \mathrm{vol} \%)$ & $(\mathrm{vol} / \mathrm{vol} \%)$ & $($ vol/vol \%) \\
\hline 0 & 0 & 0 & 0 & 0 & 0 \\
\hline 1 & 1.3 & 5.4 & 23.9 & 69.0 & 1.6 \\
\hline 2 & 3.5 & 5.9 & 20.5 & 73.0 & 0.5 \\
\hline 5 & 2.6 & 7.9 & 19.5 & 71.0 & 1.7 \\
\hline 10 & 11.9 & 5.9 & 28.1 & 62.5 & 3.5 \\
\hline
\end{tabular}

Table S5. The mass balance for the hydrodeoxygenation experiments

\begin{tabular}{|l|l|l|l|l|l|}
\hline $\begin{array}{l}\text { Initial } \\
\text { pyrolysis oil }\end{array}$ & Dodecane (solvent) & WIBO + Solvent & WSBO & Char & Gas \\
\hline 7.06412 & 0.0000 & 16.43312 & 2.35790 & Negligible & n.d. ${ }^{*}$ \\
\hline 7.02025 & 7.0653 & 16.98718 & 1.78247 & Negligible & n.d. \\
\hline 6.99809 & 14.0136 & 16.71169 & 2.02594 & Negligible & n.d. \\
\hline
\end{tabular}

Table S7. The composition (mass fractions) of water insoluble pyrolysis oil (WSPO) analysed by GCMS for the hydrodeoxygenation experiments.

\begin{tabular}{|l|l|l|l|}
\hline Compound & CAS Number & Mol Formula & Mass fraction \\
\hline Dodecane (Solvent) & $112-40-3$ & $\mathrm{C} 12 \mathrm{H} 26$ & 0.9168 \\
\hline Dimethyl ether & $115-10-6$ & $\mathrm{C} 2 \mathrm{H} 60$ & 0.000055 \\
\hline Ethanol & $64-17-5$ & $\mathrm{C} 2 \mathrm{H} 60$ & 0.000358 \\
\hline Furan & $110-00-9$ & $\mathrm{C} 4 \mathrm{H} 40$ & 0.000128 \\
\hline Methyl acetate & $79-20-9$ & $\mathrm{C} 3 \mathrm{H} 6 \mathrm{O} 2$ & 0.000264 \\
\hline Propionic acid, ethyl ester & $105-37-3$ & $\mathrm{C} 5 \mathrm{H} 1002$ & 0.000086 \\
\hline Diethyl acetal & $105-57-7$ & $\mathrm{C} 6 \mathrm{H} 1402$ & 0.000054 \\
\hline 1-Hydroxy-2-butanone & $5077-67-8$ & $\mathrm{C} 4 \mathrm{H} 802$ & 0.001068 \\
\hline Cyclopentanone & $120-92-3$ & $\mathrm{C} 5 \mathrm{H} 80$ & 0.000846 \\
\hline Furan, 2-ethyl-5-methyl- & $1703-52-2$ & $\mathrm{C} 7 \mathrm{H} 100$ & 0.000119 \\
\hline Cyclopentanone, 2-methyl- & $1120-72-5$ & $\mathrm{C} 6 \mathrm{H} 100$ & 0.000059 \\
\hline 2-Methyl-2-cyclopentenone & $1120-73-6$ & $\mathrm{C} 6 \mathrm{H} 80$ & 0.000495 \\
\hline Phenol & $108-95-2$ & $\mathrm{C} 6 \mathrm{H} 60$ & 0.001285 \\
\hline p-Cresol, 2-methoxy- & $93-51-6$ & $\mathrm{C} 8 \mathrm{H} 10 \mathrm{O} 2$ & 0.000016 \\
\hline 2-Methyl-1-phenyl-1-pentanol & $73177-67-0$ & $\mathrm{C} 12 \mathrm{H} 180$ & 0.000516 \\
\hline p-Ethylguaiacol & $2785-89-9$ & $\mathrm{C} 9 \mathrm{H} 12 \mathrm{O} 2$ & 0.009510 \\
\hline Guaiacylpropane & $2785-87-7$ & $\mathrm{C} 10 \mathrm{H} 1402$ & 0.064159 \\
\hline Vanillin & $121-33-5$ & $\mathrm{C} 8 \mathrm{H} 803$ & 0.000770 \\
\hline (E)-Isoeugenol & $97-54-1$ & $\mathrm{C} 10 \mathrm{H} 12 \mathrm{O} 2$ & 0.000158 \\
\hline Acetoguaiacon & $498-02-2$ & $\mathrm{C} 9 \mathrm{H} 10 \mathrm{O} 3$ & 0.000000 \\
\hline Guaiacylacetone & $2503-46-0$ & $\mathrm{C} 10 \mathrm{H} 12 \mathrm{O} 3$ & 0.000127 \\
\hline 2-Naphthol, 3-methoxy- & $18515-11-2$ & $\mathrm{C} 11 \mathrm{H} 1002$ & 0.000448 \\
\hline Dibenzo[b,d]cycloheptanone, 1,2,9-trimethoxy- & - & $\mathrm{C} 18 \mathrm{H} 18 \mathrm{O} 4$ & 0.002712 \\
\hline Total & & & 1.0000 \\
\hline & & & \\
\hline
\end{tabular}




\section{Process modelling}

The overall process diagram in shown Fig. S1. (identical to Fig. 3). The following sections will present the process description of sub-processes (100-500) and their processing steps. The applied modelling techniques and underlying assumptions are discussed in the following.

\section{Section 100: Biomass pyrolysis}

Fig. S2, adapted from Jones, et al., ${ }^{\left[{ }^{[1]}\right.}$ shows the process flow diagram for the pyrolysis section. In this section, the grinded biomass is firstly dried and then fed to a short residence time $(<1$ second) circulating fluidized bed reactor (R-101) where it is converted to a widespread range of components which can be roughly classified into non-condensable gases, condensable gases and char. Sand acts as the fluidization and heating medium, and together with char are separated at Cyclone-101. The char is burned in the combustor (E-101) in order to heat the circulating sand which in turn will supply the required energy for the endothermic pyrolysis reactions. The reaction effluents are quickly quenched in order to suppress undesirable reactions, which otherwise would degrade the products in favour of char and light gases. A fraction of light gases are also burned in the combustor and the rest are recycled to the reactor. The condensable products of pyrolysis reactions form a brownish mixture which contains significant amount of oxygenates and is chemically unstable. Furthermore, it is has lower energy content and is immiscible with the petroleum fuel. Therefore, it is sent to Section 200 for upgrading.

\section{Section 200: integrated pyrolysis oil upgrading}

As shown in Figure $\mathrm{S} 3$, and extensively discussed in the manuscript, a new reaction network was developed for upgrading the pyrolysis oil. In the new process, firstly the pyrolysis oil is split between two first-stage upgrading reactors. The split fraction is an optimization variable in order to minimize the hydrogen requirements. The fraction of pyrolysis oil sent for hydrothermal upgrading is firstly mixed with water and then sent to the hydrothermal reactor ( $\mathrm{R}-202)$ at near-supercritical conditions ( $350 \mathrm{oC}$ and $200 \mathrm{bar})$. The rest of the pyrolysis oil is firstly mixed with the dodecane solvent and then fed into a trickle flow reactor (R-201) where it reacts with hydrogen. The effluents of both first-stage upgrading reactors are cooled and phase separated. The water insoluble pyrolysis oil (WIPO) is sent to the send-stage hydrodeoxygenation reactor (R-203) where hydrodeoxygenation reactions remove any remaining oxygen from the fuel. The water soluble pyrolysis oil (WSPO) is sent to the reformer for hydrogen production in Section 500.

\section{Section 300 and 400: Separation and hydrocracking}

The flow diagram for Sections 300 and 500 is shown in Fig. S4. The upgraded effluent are further refined in Section 300 through a sequence of distillation columns. The dissolved light gases are separated in Column T301 and sent to Section 600 for hydrogen production. Then, the naphtha fraction is separated in Column T302. The boiling point of the dodecane solvent overlaps with the boiling range of the biodiesel product. Therefore, two distillation columns were considered. A fraction of diesel, which is lighter than the dodecane solvent, is separated from the top of Column T-303 and the heavier fraction is separated from the bottom of Column T-304. The overhead of Column T-304 mostly consists of the dodecane solvent and is recycled to the first-stage hydrodeoxygenation reactor. Separation section is also integrated to a hydrocracker reactor (R-401), where heavy-ends are converted to higher-value lighter products.

\section{Section 500: Hydrogen production}

The process flow diagram is shown in Fig. S5, Jones, et al., ${ }^{[52]}$. The water soluble pyrolysis oil (WSPO) from Upgrading Section was used in the reformer (R-501) where it is converted to the syngas, a mixture of carbon oxides, hydrogen, and water. The overall hydrogen yield is further improved in a low temperature reactor, before being sent to the pressure swing adsorption (PSA) for separation. The tail gas (CO, CO2 and unseparated hydrogen) is recycled to the reformer and burned in the combustion zone. The excess heat is used for producing steam. 


\section{Process modelling and implementation considerations}

The process throughput was 2000 ton per day hybrid poplar, similar to Jones, et al.'s study ${ }^{[11]}$. The process modelling was conducted using Aspen plus ${ }^{\mathrm{TM}}$ simulator. The required information for modelling Pyrolysis Section and Hydrogen Production Section were adapted from [S2]. The required information for modelling reactors in Upgrading Section were modelled based on the yield results from the experimental program as reported in Tables S1-S7. In modelling Separation Section (300), the specifications of the distillations columns were adjusted so the gasoline and diesel products have the same quality as [S2]. The hydrocracking yield in Section 500 was also adopted from this study. The operating conditions are summarized in Table S8. The distillation columns were modelled using RADFRAC unit operation in Aspen Plus. The pressure swing adsorption was modelled using "SEP" unit operation in Aspen Plus ${ }^{\mathrm{TM}}$, assuming $90 \%$ separation efficiency. The costs of conventional unit operations (e.g., distillations, compressors) were evaluated using Aspen Economic Analyzer $^{\mathrm{TM}}$. The costs of nonconventional unit operations (e.g., reformer, pyrolyzer) were calculated by scaling with respect to economic data ${ }^{[52]}$.

Table S8. The modelling approach and operating conditions for major reactors.

\begin{tabular}{|l|l|l|l|l|l|}
\hline Reactor & Description & $\mathbf{T}(\mathbf{C})$ & $\mathbf{P}$ (MPa) & $\begin{array}{l}\text { Modelling } \\
\text { approach }\end{array}$ & Ref. \\
\hline R101 (Fig S2) & Pyrolysis reactor & 500 & 0.108219 & Yield & {$[$ S2] } \\
\hline R201 (Fig S3) & $\begin{array}{l}\text { First stage Hydrodeoxygenation } \\
\text { reactor }\end{array}$ & 250 & 5 & Yield & $\begin{array}{l}\text { Experimental } \\
\text { results }\end{array}$ \\
\hline R202 (Fig S3) & $\begin{array}{l}\text { First stage Hydrothermal upgrading } \\
\text { reactor }\end{array}$ & 380 & 22 & Yield & $\begin{array}{l}\text { Experimental } \\
\text { results }\end{array}$ \\
\hline R203 (Fig S3) & $\begin{array}{l}\text { Second stage Hydrodeoxygenation } \\
\text { reactor }\end{array}$ & 251 & 17.2 & Yield & [S2] \\
\hline R401 (Fig S4) & Hydrocracker & 675 & 8.9 & Yield & [S2] \\
\hline R701 (Fig S5) & Reformer reactor & 850 & 2.6 & $\begin{array}{l}\text { Chemical } \\
\text { Equilibrium }\end{array}$ & [S2] \\
\hline R-702 (Fig S5) & High temperature gas shift reactor & 353 & 2.5 & Conversion & [S2] \\
\hline
\end{tabular}

\section{Reference}

[S1] C.J.Richard, B.Patel, D.Chadwick, K.Hellgardt, (2013). Biomass and Bioenergy, 56, 446-455.

[S2] S.B. Jones, J.E. Holladay, C. Valkenburg, D.J. Stevens, C.W. Walton, C. Kinchin, D.C. Elliott, S. Czernik. Production of Gasoline and Diesel from Biomass via Fast Pyrolysis, Hydrotreating and Hydrocracking: A Design Case. US Department of Energy 2009; Technical Report. 


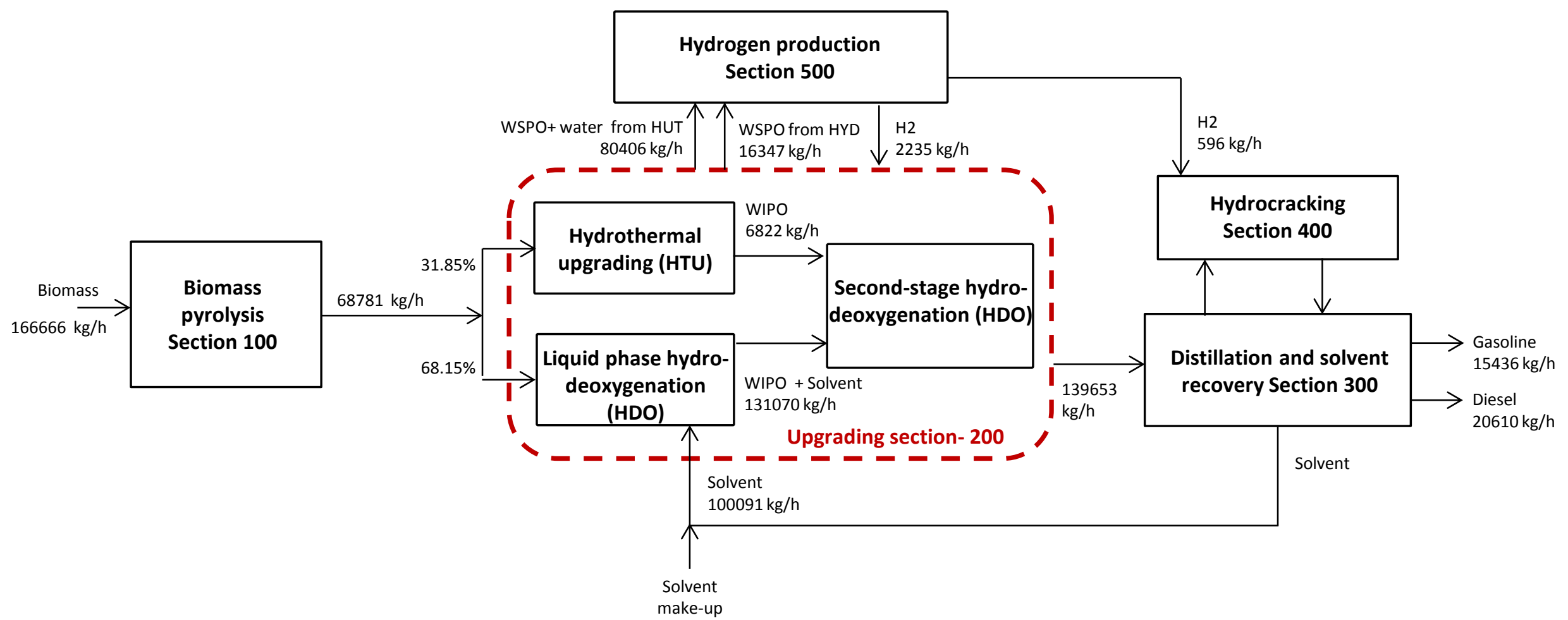

Fig. S1. The overall process block diagram - this figure is identical to Fig $\mathbf{3}$ in the manuscript. 


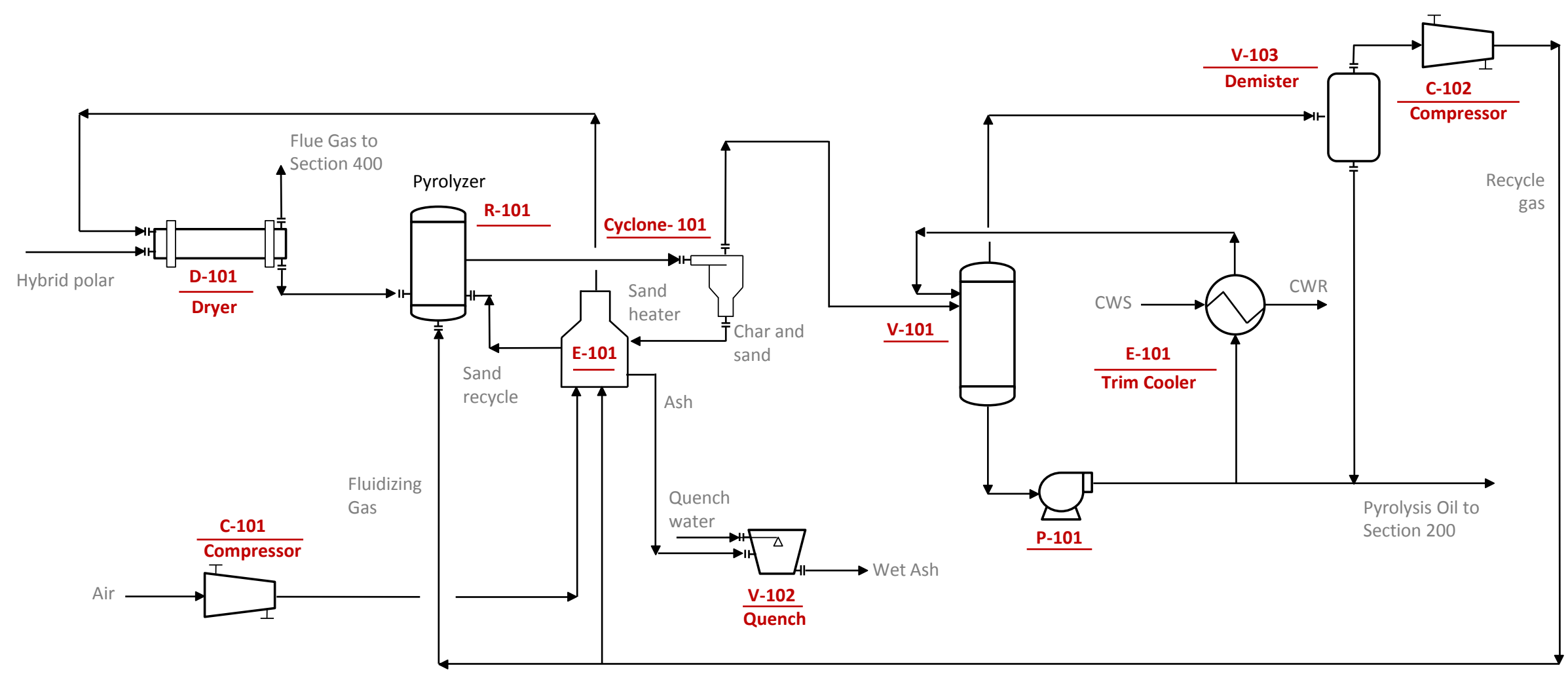

Fig. S2. Biomass Pyrolysis Section (100) - adapted from Jones, et al., ${ }^{[51]}$ 


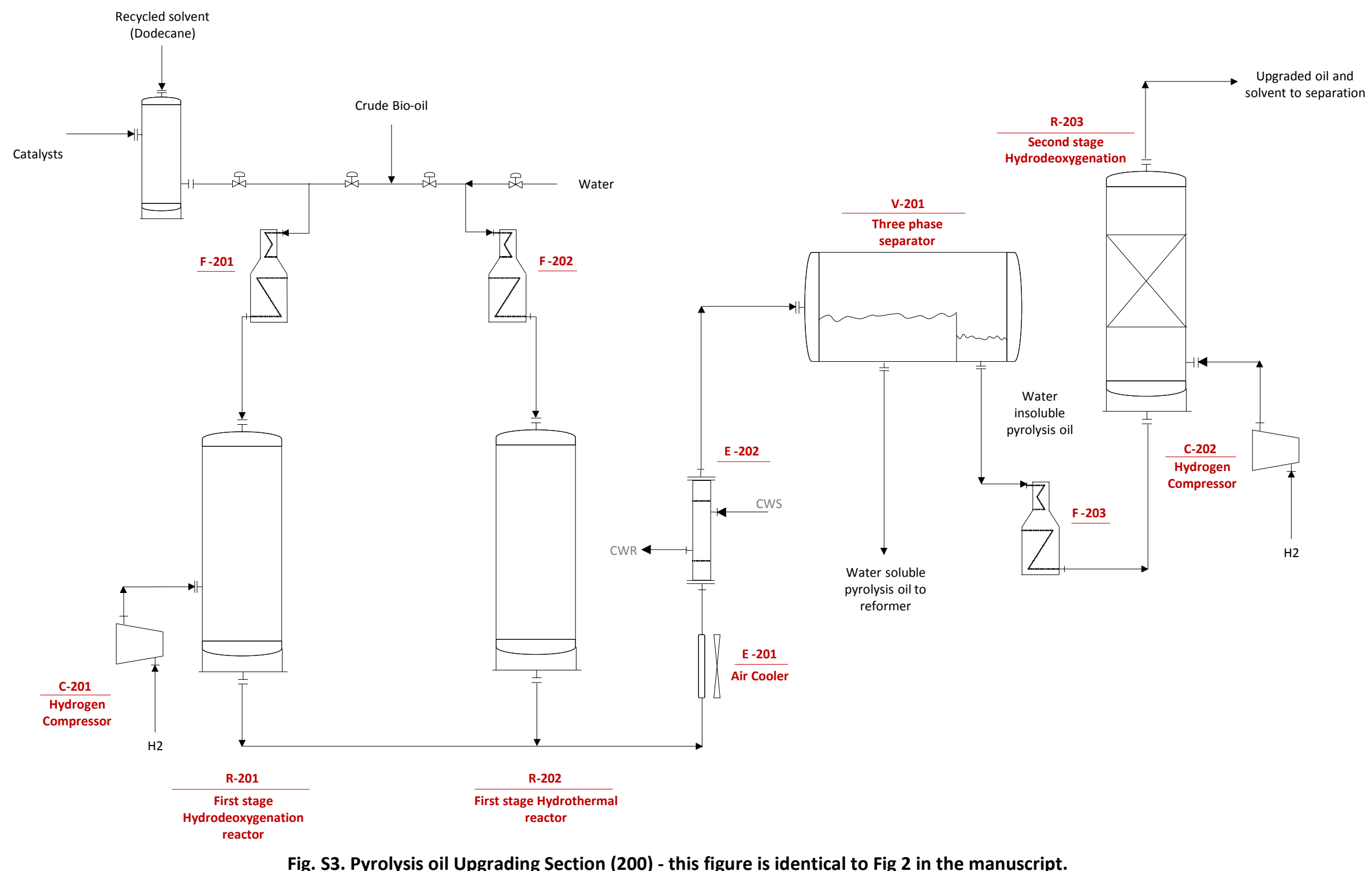




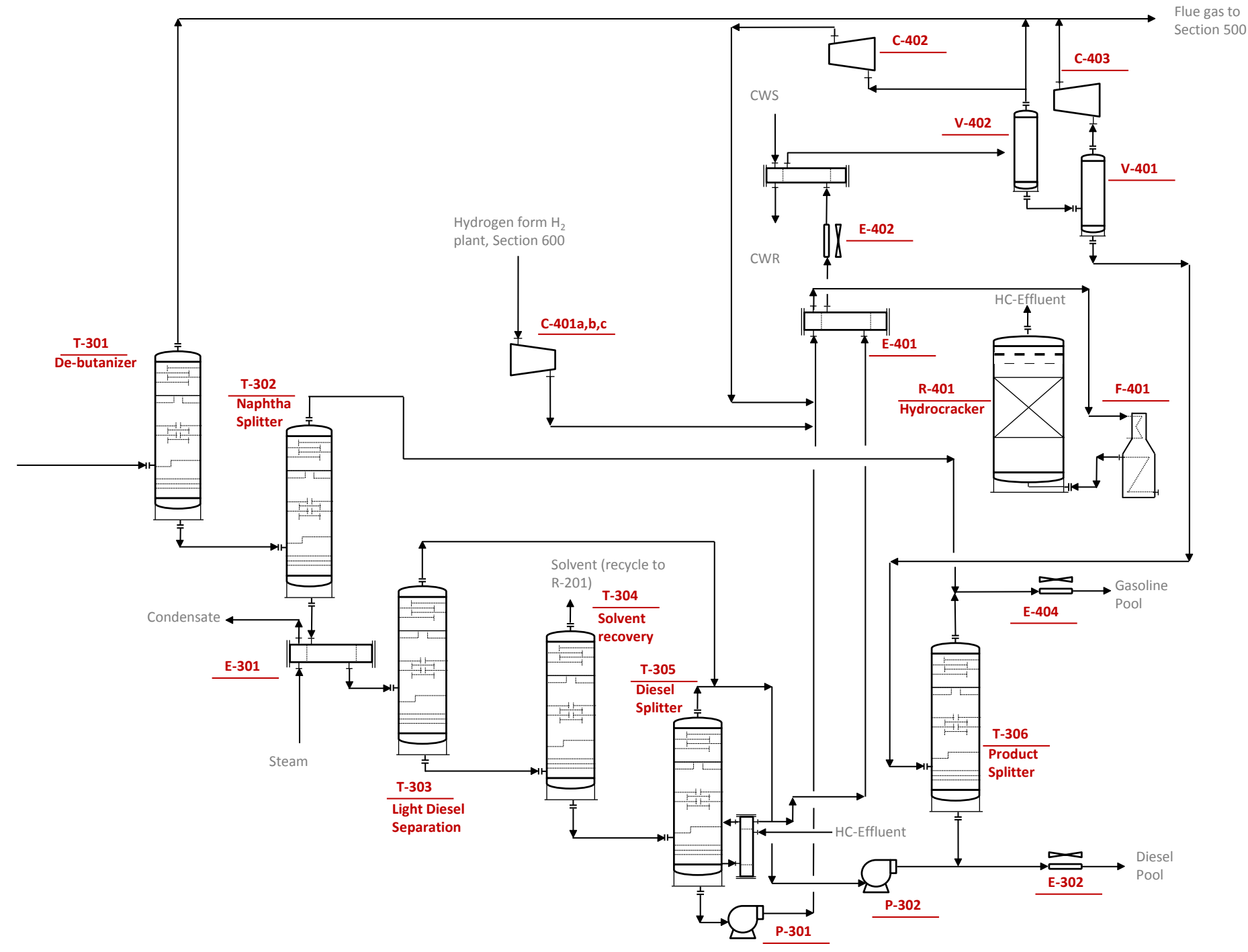

Fig. S4. Separation Section (300) and Hydrocracking Section (400) 


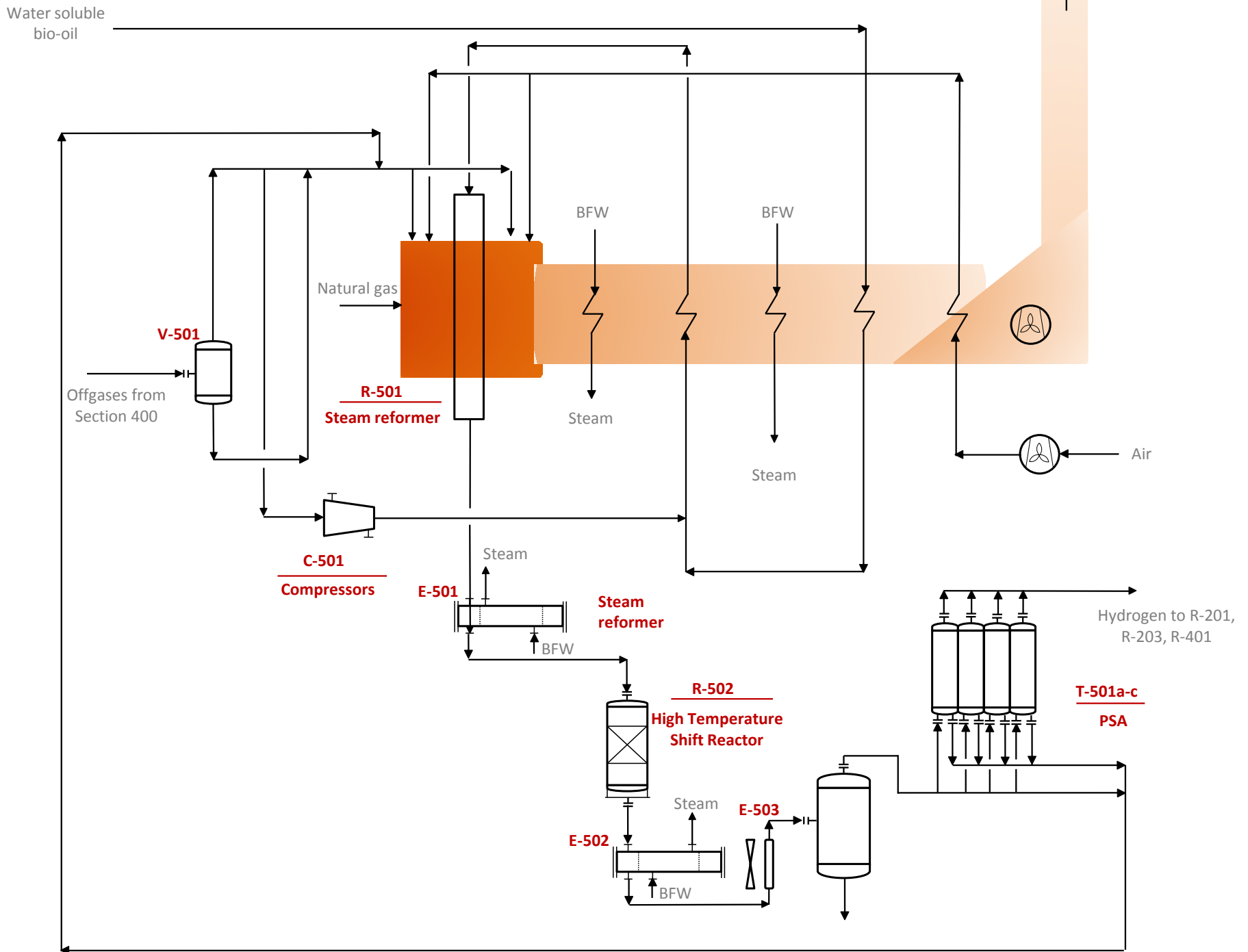

Fig. S5. Hydrogen production Section (500) - adapted from Jones, et al., [51] 